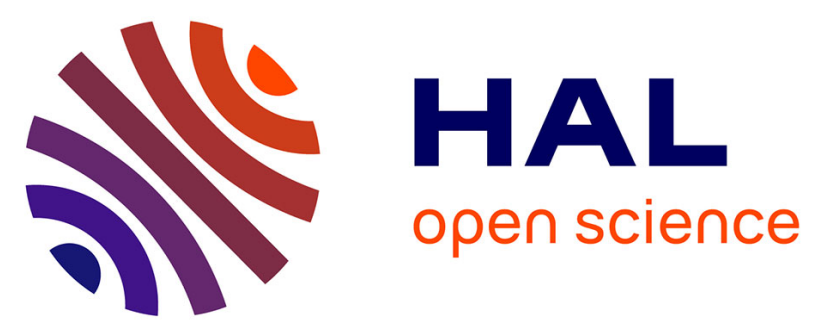

\title{
Hydrothermal alteration of the Ediacaran Volyn-Brest volcanics on the western margin of the East European Craton
}

Jan Środon, Oksana Kuzmenkova, Jan Stanek, Sabine Petit, Daniel Beaufort, H. Albert Gilg, Sirle Liivamägi, Magdalena Goryl, Leszek Marynowski, Marek Szczerba

\section{To cite this version:}

Jan Środon, Oksana Kuzmenkova, Jan Stanek, Sabine Petit, Daniel Beaufort, et al.. Hydrothermal alteration of the Ediacaran Volyn-Brest volcanics on the western margin of the East European Craton. Precambrian Research, 2019, 325, pp.217-235. 10.1016/j.precamres.2019.02.015 . hal-02363102

\section{HAL Id: hal-02363102 \\ https://cnrs.hal.science/hal-02363102}

Submitted on 1 Dec 2020

HAL is a multi-disciplinary open access archive for the deposit and dissemination of scientific research documents, whether they are published or not. The documents may come from teaching and research institutions in France or abroad, or from public or private research centers.
L'archive ouverte pluridisciplinaire HAL, est destinée au dépôt et à la diffusion de documents scientifiques de niveau recherche, publiés ou non, émanant des établissements d'enseignement et de recherche français ou étrangers, des laboratoires publics ou privés. 
Hydrothermal alteration of the Ediacaran Volyn-Brest volcanics on the western margin

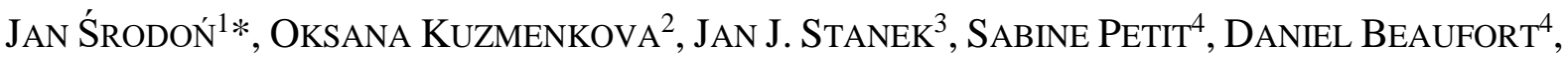

${ }^{1}$ Institute of Geological Sciences, Polish Academy of Sciences, Krakow, Poland

(*corresponding author: ndsrodon@cyf-kr.edu.pl)

${ }^{2}$ Research and Production Center for Geology, Minsk, Belarus

$11{ }^{3}$ Institute of Physics, Jagiellonian University, Krakow, Poland

${ }^{4}$ Institut de Chimie des Milieux et Matériaux de Poitiers, Univ. Poitiers - CNRS, France

${ }^{5}$ Engineering Geology, Technical University of Munich, Munich, Germany

${ }^{6}$ University of Silesia, Faculty of Earth Sciences, Sosnowiec, Poland

\section{Abstract}

The Ediacaran continental flood basalts and associated tuffs were studied to identify and quantify alteration processes by means of XRD and chemistry, supplemented by Mössbauer and FTIR spectroscopies, petrography, oxygen and iron isotopes, K-Ar dating, and organic geochemistry. Two superimposed alteration processes were identified: the Ediacaran hydrothermal alteration, induced by meteoric waters, heated and put in motion by the cooling basalt, and the Caledonian and/or Variscan potassic alteration. The degree of basalt alteration was quantified using as an index the sum of primary minerals in the bulk rock. The sequence of minerals dissolved and crystallized during the hydrothermal alteration was established. The alteration resulted in the loss of $\mathrm{Ca}$ (dissolution of plagioclases), compensated by the gain of 
water and $\mathrm{Mg}$ (crystallization of clays), and proceeded from the edges of the basalt flows in an oxidizing environment, evidenced by the increasing amount of hematite and $\mathrm{Fe}^{3+} / \mathrm{Fe}^{2+}$ ratio of the bulk rock. Cyanobacteria were active in the hydrothermal system, most probably responsible for the measured negative $\delta^{56} \mathrm{Fe}$ values and more reducing conditions at the stage of intense alteration. Chlorophaeite (palagonite), following quartz as the earliest petrographically identifiable basalt alteration product was found to vary systematically from fully isotropic to birefringent. The chlorophaeite was identified as a mixture of $\mathrm{Fe}$ montmorillonite and Fe-saponite, identical with griffithite and oxysmectites, probably preceded by a finer-grained ferrosaponite at the isotropic stage. REE content of chlorophaeite indicates basaltic volcanic glass (sideromelane) as the major source of material. REE in clays are contained mostly in the dioctahedral smectite, while in the bulk rock mostly in phosphates. The smectite characteristics and $\mathrm{Mg}$ enrichment are indicative of the hydrothermal basalt alteration process, which perhaps was dominant also on Mars.

Both mineral and chemical composition of tuffs vary continuously from basaltic to felsic, the latter close to the measured rhyodacite composition, dominated by quartz and feldspars. The basaltic tuffs resemble the most altered basalts but contain also abundant albite and chlorite, indicative of higher alteration temperatures, up to $220^{\circ} \mathrm{C}$. Tuff composition indicates stronger component of felsic volcanism in the trap formation than evidenced by the preserved bodies of effusive rocks.

Key words: aluminoceladonite; chlorophaeite; cyanobacteria; griffithite; ferrosaponite; Martian smectite, palagonite.

\section{Introduction}


Sub-surface (non-related to weathering) alteration of basalts is a widespread and intensely studied phenomenon, known from three major Earth environments: submarine hydrothermal, burial diagenetic/metamorphic, and continental hydrothermal.

A good example of submarine hydrothermal alteration within a $60-165^{\circ} \mathrm{C}$ measured temperature range is the 1300 m profile of DSDP Hole 504B south of the Costa Rica Rift in the Pacific (Alt et al., 1986; Shau and Peacor, 1992). A clear alteration sequence was observed: iron oxides, saponite, celadonite, phillipsite, anhydrite, and aragonite formed below $150^{\circ} \mathrm{C}$, and mixed-layer saponite-chlorite, corrensite, corrensite/chlorite, and finally chlorite, minor talc, quartz, pyrite, epidote, laumontite, heulandite, prehnite, actinolite, and albite formed in deeper, hotter parts. Altered basalt becomes a sink for $\mathrm{Mg}$ and $\mathrm{K}$ from seawater, affecting the element mass balance of the oceans. From the saponitic to chloritic end of the trioctahedral clay sequence, $\mathrm{Si} /(\mathrm{Si}+\mathrm{Al})$ ratio decreases, while $\mathrm{Fe} /(\mathrm{Mg}+\mathrm{Fe})$ increases. In another submarine site (801), Alt et al. (1992) observed a range of alteration products from pure saponite to almost pure dioctahedral smectite, accompanied by pyrite and calcite. Other samples contain celadonite, glauconite, and iron oxides. With progressing alteration (measured by $\mathrm{H}_{2} \mathrm{O}^{+}$), an increase in $\delta^{18} \mathrm{O}$, iron oxidation and $\mathrm{K}_{2} \mathrm{O}$ is observed, while $\mathrm{CaO}$ decreases, but $\mathrm{MgO}$ does not show a clear trend.

A particularly clear sequence of burial metamorphic alteration zones was documented (Schmidt, 1993; Schmidt and Robinson, 1997) from the $8 \mathrm{~km}$ thick pile of the Keweenawan Middle Proterozoic continental subaerial rift basalts, outcropping on the shore of Lake Superior, and known for native copper deposits. At the top of sequence, saponite is dominant, and going down section, random chlorite-smectite and corrensite appear, accompanied by laumontite and albite, then chlorite with prehnite and pumpellyite, and finally epidote and actinolite (greenshist facies). Albite is the most abundant alteration product of Ca-rich plagioclase. Fe oxides were not reported. Celadonite occurs sporadically. Like in the 
submarine alteration, from the saponitic to chloritic end of the trioctahedral clay sequence $\mathrm{Si} /(\mathrm{Si}+\mathrm{Al})$ ratio decreases, while $\mathrm{Fe} /(\mathrm{Mg}+\mathrm{Fe})$ increases. Strong control of porosity and permeability over the extent of alteration is evident: massive flow centres have less advanced alteration than porous, thus permeable tops and bottoms.

Subaerial hydrothermal alteration of basalts has been most thoroughly studied in Iceland, where data measured in active hydrothermal systems were used to assess temperature ranges of subsequent alteration zones, analogous to burial and marine hydrothermal (Franzson et al., 2008): smectite+zeolites correspond to the $50-200^{\circ} \mathrm{C}$ range, trioctahedral mixed layer clays dominate over the $200-220^{\circ} \mathrm{C}$ range, then chlorite takes over and albitization starts, epidote appears at ca. $240^{\circ} \mathrm{C}$, actinolite at $275^{\circ} \mathrm{C}$, and amphibole above $350^{\circ} \mathrm{C}$. Analogous basalt alteration sequences have been identified in other hydrothermal fields, e.g. in a geothermal well in Hawaii (Stone and Fan, 1978).

This review demonstrates that the alteration of basalts in three different environments proceeds via a very similar sequence of mineral assemblages, which indicates dominant control of the rock chemistry over the alteration mineralogy, with porosity and permeability affecting the reaction progress, and in particular the pathway of smectite to chlorite transition (Robinson et al., 2002).

Similar qualitative mineralogical data (e.g. Juskowiakowa, 1974; Kuzmenkova, 2005; Derevska et al., 2006; Emetz et al., 2006; Kuzmenkova et al., 2006; Melnychuk, 2006; Shumlyanskyy and Tsymbal, 2006; Skakun et al., 2006) are available also for the Ediacaran Volyn-Brest volcanics of the East European Craton (EEC; Figure 1) and they inspired the present study. Our study was focused on adding a quantitative mineralogical dimension to the knowledge of hydrothermal basalt alteration, on understanding the conditions of this alteration, and on discriminating the effects of younger alteration phenomena. The clay alteration products were studied in most detail to characterize the substrate on which the 
101 Ediacaran weathering of basalts took place (Liivamägi et al., 2018). It was also hoped that

102 better understanding of the Ediacaran basalt hydrothermal alteration may be useful as a model 103 for the origin of clays on Mars. They have been detected both by remote and in-situ methods

104 as the main products of basalt alteration in the Noachian age (e.g., Ehlmann et al., 2011a,b;

105 Carter et al., 2013; Chemtob et al., 2015). The origin of these clay minerals is currently

106 debated, and potential formation environments include subsurface hydrothermal systems,

107 subaerial weathering profiles, lacustrine environments, and steam or a supercritical 108 atmosphere of water and $\mathrm{CO}_{2}$ (e.g., Ehlmann et al., 2011a,b; Vaniman et al., 2014; Bishop et 109 al., 2018; Cannon et al., 2018). Here, we identify mineralogical and geochemical signatures of 110 subsurface hydrothermal clay deposits that can be used to constrain clay formation 111 environments on Mars.

\section{Study area}

115 The Volyn-Brest Ediacaran flood basalts, up to $500 \mathrm{~m}$ of lavas and volcanoclastics, cover $116140,000 \mathrm{~km}^{2}$ of the western margin of the East European Craton. The original volcanic cover

117 extended much further east and north, as evidenced by isolated erosional remnants in these 118 areas (Figure 1). Towards the southeast, the volcanic cover continues to an unknown distance, 119 deeply buried below Paleozoic sediments of the Teisseyre-Tornquist Zone (Pacześna, 2010), 120 which separates the Precambrian from the Paleozoic platform. In Volyn (northwest Ukraine 121 north of Lvov), the Ediacaran basalts occur over ca. $80 \mathrm{~km}^{2}$ at the surface or under a thin 122 cover of the Cretaceous rocks and have been used as building stones since XVII century 123 (Rajchel, 2012). In other regions, they are covered by the Late Ediacaran clastic sediments 124 and younger deposits. 
The Volyn-Brest trap region is a continental flood basalt province, analogous to the well- known Columbia River, Deccan, Paraná, or Siberian traps (Kuzmenkova et al., 2010). It is considered a product of the supercontinent Rodinia rifting, which detached Amazonia from Baltica by opening of the Tornquist Ocean in the Late Ediacaran (Poprawa et al., 1999; Nawrocki and Poprawa, 2006). Deep root bodies of the basalt province were identified recently by geophysical methods in the Teisseyre-Tornquist Zone, SE of Brest (Mazur et al., $1312018 a)$.

Volyn basalts have been studied since the mid-19th century, and particular interest was generated by finding a native copper mineralization (Małkowski, 1929). These early studies (conf. Białowolska et al., 2002 for references) were carried out on rocks from the Volyn outcrops, later also on the core materials from Belarus, Poland and Ukraine (Ushakova, 1962; Juskowiak and Ryka, 1967; Makhnach and Veretennikov, 1970; Juskowiakowa, 1971; Compston et al., 1995; Białowolska et al., 2002; Bakun-Czubarow et al., 2002; Emetz et al., 2004; Kuzmenkova, 2007; Nosova et al., 2008; Kuzmenkova, 2011; and many others). Recent investigations, summarized in a monograph (Shumlyanskyy, ed., 2006), were centered on the genesis of native copper mineralization. All of these studies were devoted mainly to

141 geochronology, geochemistry, and petrographic observations of mineral successions. measurements of the whole rock gave a broad range of $690-540$ Ma. The ${ }^{40} \mathrm{Ar} /{ }^{39} \mathrm{Ar}$ whole

144 rock method yielded two age groups: 590-560 Ma (magma crystallization) and 393-369 Ma

145 (potassic alteration). The $\mathrm{Rb}-\mathrm{Sr}$ isochron method applied to four whole rock samples gave an 146 imprecise age of $552 \pm 59 \mathrm{Ma}$, while $\mathrm{U}-\mathrm{Pb}$ zircon ages range from $551 \pm 4 \mathrm{Ma}$ to $573 \pm 14 \mathrm{Ma}$.

147 Geochemical studies identified the trap rocks as within plate continental basalts and 148 documented vertical zonation of the trap: picrobasalts and subalkaline olivine basalts in the 149 lower basalt flows are covered locally (Figure 1) by felsic rocks (andesite, dacite, rhyodacite, 
trachyandesite), and tholeiites dominate the upper flows, all accompanied by more or less

151 abundant tuffs (Bakun-Czubarow et al., 2002; Kuzmenkova et al., 2008; Nosova et al., 2008).

152 The Ediacaran paleosols are developed both on the lower (Kuzmenkova et al., 2011) and on

153 the upper basalts (Levykh, 1999; Liivamägi et al., 2018), documenting the continental,

154 subaerial origin of the volcanic sequence.

155 Since the findings of native copper (Małkowski, 1929) and celadonite (Kamieński,

156 1929), later confirmed by Lazarenko (1956), it was realized that Volyn basalts underwent

157 widespread hydrothermal alteration of variable intensity. Shumlyanskyy and Tsymbal (2006)

158 recognized this variable degree of alteration and characterized geochemically the alteration

159 sequence: oxidation of iron; increase of $\mathrm{MgO}, \mathrm{K}_{2} \mathrm{O}, \mathrm{LOI}, \mathrm{Rb}, \mathrm{Ba}, \mathrm{Zr}, \mathrm{Nb}$, Ta, Th, $\mathrm{U}$; decrease

160 of $\mathrm{CaO}$ and $\mathrm{Sr}$. They observed more intense alteration of tuffs compared to the flood basalts,

161 but they interpreted the exceptionally high $\mathrm{MgO}$ content of some tuffs as reflecting the 162 primary volcanic composition. Melnychuk (2006) documented carbonate, zeolite, and 163 prehnite-pumpellyite zones of hydrothermal alteration in the flood basalts and volcanic tuffs.

164 In Volyn and Belarus, i.e. outside the Teisseyre-Tornquist Zone, the basalts have 165 never been deeply buried, as indicated by regional organic geochemistry data for overlying 166 sediments (Nehring-Lefeld et al., 1977) and confirmed recently by studying the Ediacaran 167 paleosols developed on basalts (Liivamägi et al., 2018) and hopane biomarkers in the overlying Ediacaran sediments (Goryl et al., 2018). Initially, a "fresh" appearance of the

169 unaltered sections was used as evidence of the lack of regional metamorphic or advanced 170 diagenetic changes (Ushakova, 1962; Juskowiak and Ryka, 1967; Makhnach and 171 Veretennikov, 1970). Juskowiakowa (1974) observed that the alteration develops from the 172 upper and lower surfaces of the lava flows, it may be complete in thin flows and tuffs or 173 tectonic zones, and it involves the development of chlorite, illite and celadonite. The 174 alteration sequence was characterized by the microscopic studies of Volyn native $\mathrm{Cu}$ deposits 
175 (Derevska et al., 2006; Emetz et al., 2006; Skakun et al., 2006). Plagioclase (andesine176 anorthite), clinopyroxene, magnetite, ilmenite, titanomagnetite, volcanic glass, and rare 177 olivine (often recognized only as prehnite pseudomorphs) were identified as primary basaltic 178 components. Clinochlore, hematite, albite, and pumpellyite were identified as pre-ore 179 minerals; prehnite, laumontite, wairakite, quartz, and K-spar as syn-ore minerals; and quartz, 180 stilbite, mordenite, heulandite, thomsonite, tri- and dioctahedral smectite, chlorite, 181 vermiculite, calcite, analcime, barite, and kaolinite as post-ore minerals. Similar composition, 182 including a wider range of zeolite minerals, was reported by Kuzmenkova (2005). 183 Kuzmenkova et al. (2006) characterized in detail glassy-looking accumulations of dark 184 material, described from various basalts under the name "chlorophaeite" and present even in 185 very fresh-looking basalts - the equivalent of palagonite (conf. review by Stroncik and 186 Schmincke, 2002), of the late-magmatic lithogel of Simanovich et al. (1986), and probably of 187 glass of Emetz et al. (2006). Smectite, chlorite and analcime were identified in chlorophaeite 188 accumulations. Mysiak et al. (2016) reported native $\mathrm{Cu}$ and $\mathrm{Ag}$ occurring along with 189 hydrothermal minerals, while native $\mathrm{Fe}, \mathrm{Sn}, \mathrm{Al}$, chlorides of $\mathrm{Sn}$ and $\mathrm{Fe}$, and a FeCrNiTi alloy 190 in pneumatolytic veins cutting the hydrothermal alteration zones. Native Fe was reported also 191 by Kvasnytsya et al. (2006). Kuzmenkova (2007) investigated the felsic rocks (rhyodacites) and found large 193 amounts of quartz, K-spar, albitized plagioclase, and chlorite+biotite pseudomorphs after 194 pyroxene. The chemical composition of tuffs is also much more variable than flood basalts, 195 demonstrating higher $\mathrm{K}$ and $\mathrm{Na}$ and lower $\mathrm{Ca}$. Saponite, mixed-layer chlorite-smectite, 196 hydromica, analcime, other zeolites, and hematite were identified as alteration minerals in the 197 tuffs. 
quantifying the alteration process, investigating its relationship to the conditions on the

201 Ediacaran land, and investigating in more detail the iron-rich smectite, which is the main 202 alteration product.

\section{Materials}

All investigated samples (locations in Figure 1) are core materials, except for the Tashki samples, collected from a quarry. Present depth, macroscopic characteristics, and location of a sample in the trap profile (lower, middle, and upper volcanogenic strata) are given if available in Inline Supplementary Tables 1 and 2, listing separately flood basalts, clays from veins and cavities in basalts, felsic rocks, and tuffs, according to the macroscopic identification. Several

211 chlorophaeite accumulations, studied earlier by Kuzmenkova et al. (2006) were also investigated, some of them only by FTIR because of small amount of the available material, along with the reference montmorillonite samples 4529-2 and 4517-1 from the paleosol,

214 developed on the Volynian basalt (Liivamägi et al., 2018). In three cases (Mokrany-1, 2, and 215 3), both basalt sample and a chlorophaeite accumulation separated from this basalt sample 216 were available. Additional paleosol samples were used in the organic geochemistry study.

\section{Methods}

The main techniques used in this study are: quantitative X-ray diffraction of the bulk rock (QXRD) using in-house Q-Min software (by Dr. M. Szczerba, Institute of Geological Sciences PAS), XRD of the clay fractions separated from the bulk rock, chemical analysis (major elements by X-Ray Fluorescence (XRF) and trace elements (including REE) by Laser 
borate fused disc), Mössbauer spectroscopy and iron isotope composition of the bulk rock and

226 of the clay fractions, and the K-Ar dating of clay fractions. These methods are identical to 227 those used by Liivamägi et al. (2018) in the study of paleosols developed on these basalts, and 228 their descriptions are reproduced with some modifications in the Supplementary Materials, 229 along with additional techniques applied in this study: oxygen isotope and FTIR 230 measurements of the bulk rock and the clay fraction, organic geochemistry, and petrographic 231 observations of the basalt alteration products.

\section{$232 \quad$ Results}

XRD of the bulk rock

\section{Flood basalts and chlorophaeites}

Quantitative XRD data for basalts (in wt \%) are given in Inline Supplementary Table 1, and representative XRD patterns, illustrating the encountered variability of mineral composition, are presented in Figure 2. Most common major components are calcic plagioclase, pyroxene, 240 magnetite, dioctahedral smectite, trioctahedral smectite and chlorite or mixed-layer chlorite241 smectite. Quantities of these major components vary broadly. Both di- and trioctahedral 242 smectites are present in most samples, as evidenced by separate 02 and 06 peaks (Figure 2).

243 Common minor components are: quartz, potassium feldspar of orthoclase/sanidine/sanidine 244 group (most often more abundant than quartz), and hematite. Orthoclase cannot be 245 distinguished from sanidine in the bulk rock XRD, so they are reported as a group. Rare 246 minor components are ilmenite, anatase, analcime, pseudobrookite, clinoptilolite, laumontite, 247 calcite, and siderite. Olivine, reported in published petrographic studies, was not detected. 248 The mineral compositions of two available gabbro samples fall within the limits characteristic 249 of basalts (Inline Supplementary Table 1). Three chlorophaeite accumulations were 
250 investigated by XRD along with the host basalts, but only qualitatively in glass capillaries,

251 because of the small amount of sample available. Di- and trioctahedral smectites, quartz and 252 traces of calcic plagioclase, calcite and dolomite were detected in these samples. The 253 smectitic clays are identified as separate di- and trioctahedral phases based on well resolved 25402 reflections, by analogy to the bulk basalt XRD patterns, where the 06 reflections could also 255 be recorded (compare Figures 2 and 3).

\section{$\underline{\text { Felsic rocks }}$}

258 Three rhyodacite samples were available. Their mineral composition is totally different from 259 basalts: quartz, orthoclase/sanidine/sanidine, dioctahedral clay (illite-smectite), trioctahedral 260 mica, hematite, chlorite, and a trace of kaolinite in one sample (Inline Supplementary Table 1, 261 Inline Supplementary Figure 1).

\section{$\underline{\text { Tuffs }}$}

264 Only purevolcanic materials were considered (Inline Supplementary Table 2, Inline 265 Supplementary Figure 1). The presence of minerals absent from pyroclastic materials: 266 microcline and muscovite was regarded as evidence of non-volcanic contamination (tuffites) and such samples were not included in the analysis. Mineral composition of tuffs is extremely variable. Most common components are: quartz, orthoclase/sanidine, Ca-plagioclase, dioctahedral expandable clay (illite-smectite or smectite), aluminoceladonite (identified by

$2701 \mathrm{M}_{\mathrm{tv}}$ polytype and $\mathrm{d}_{001}$ close to $9.88 \AA$, characteristic of this mineral, and distinguishing it 271 from celadonite of $\mathrm{d}_{001}=9.97 \AA$ ), and chlorite or mixed-layer chlorite-smectite. Less abundant 272 are trioctahedral smectite, albite, anatase, hematite, analcime, minor and rare are pyroxene 273 and amphibole. Locally, tuffs contain dolomite, Mn-Fe dolomite and calcite (Pinsk-26), or 274 only calcite (Tashki). 


\section{$\underline{\text { Tuff-basalt alternation }}$}

277 The contrasting characteristics of flood basalts and tuffs, emerging from the entire data set, 278 can be observed also in a single vertical profile (Kobryn), composed of three basalt flows

279 interbedded with four tuff layers free of non-volcanic contamination (Inline Supplementary 280 Table 2). Flood basalts contain trace of quartz and hematite, abundant Ca-plagioclase, 281 pyroxene, and trioctahedral smectite, and occasional minor chlorite or chlorite-smectite. Clay 282 abundances increase towards the top surfaces of the basalt flows. Tuffs contain abundant 283 quartz, orthoclase/sanidine, Ca-plagioclase and hematite, chlorite plus minor chlorite284 smectite, dioctahedral illite-smectite, and aluminoceladonite. Top samples from two tuff 285 layers contain kaolinite.

XRD identification of clay fractions

Mineral composition of $<0.2 \mu \mathrm{m}$ clay fractions, including percent smectite $(\% \mathrm{~S})$ in mixedlayer illite-smectite, measured from the diagnostic peak positions on the glycolated patterns, using the regressions based on data of Środon et al. (2009), is presented in Inline 292 Supplementary Table 3.

\section{$294 \quad$ Flood basalts}

295 Attempts to separate pure clay fractions were unsuccessful for basalts with $>60 \%$ of primary 296 minerals, despite long grinding in McCrone mill and sonification. The $<0.2 \mu \mathrm{m}$ separates 297 contain abundant plagioclase and exhibit poor orientation (Mokrany-1B in Inline 298 Supplementary Figure 2), indicating intimate intergrowth of smectite with host plagioclase crystals. More altered samples allow clean separation of clay fractions (e.g. 4504-1A in Inline 
300 Supplementary Figure 2), which contain mixtures of di- and trioctahedral smectites (Inline

301 Supplementary Figure 3), as evidenced by separate 02 and 06 reflections. Sample 4417-1

302 (Inline Supplementary Figure 2) contains corrensite, chlorite and illite-smectite with ca. 40\%

303 S. Among clays filling cavities in basalts, pure trioctahedral minerals were identified: saponite

304 (4600-1), and chlorite with minor corrensite (Kob-23: both shown in Inline Supplementary

305 Figure 2). Sample 4600-1 contains a minor admixture of corrensite in 2-0.2 $\mu \mathrm{m}$ fraction.

306

$307 \underline{\text { Tuffs }}$

308 Clay fractions of tuffs differ from flood basalts by the presence of aluminoceladonite in many

309 samples: from a trace to the dominant component. The trace amounts are associated with

310 illite-smectite of $>70 \%$ S (Inline Supplementary Figure 4: Pinsk-40), sometimes also with

311 small amounts of chlorite-smectite close to corrensite (Inline Supplementary Figure 4:

312 Tashki-10), and characterize rocks with low quartz content $(<10 \%)$. In one sample a chlorite-

313 smectite close to chlorite was dominant (Inline Supplementary Figure 4: Pinsk-40C).

314 Samples with more abundant aluminoceladonite contain illite-smectite of $<50 \% \mathrm{~S}$,

315 chlorite-smectite close to corrensite, discrete chlorite, and represent rocks with higher quartz

316 content (>10\%, Inline Supplementary Figure 4: Pinsk-46). Such samples contain abundant

317 chlorite in $0.2-2 \mu \mathrm{m}$ fraction. Most commonly, the 005 reflection of aluminoceladonite is at

$3181.978 \AA \AA$ ( $\mathrm{d}_{001}=9.90 \AA$ \&́). In the extreme case, aluminoceladonite is the dominant component,

319 (Inline Supplementary Figure 4: Kob-9B). In this sample, aluminoceladonite is accompanied

320 by a regular illite, as 005 and 003 reflections are split into two peaks.

\section{Chemical data}


The chemical data were obtained for selected bulk samples and clay fractions (Inline

325 Supplementary Table 4). The bulk rock data are grouped according to lithology into five categories: flood basalts, rhyodacites, tuffs, chlorophaeite, and vein and cavity clays. When average values are compared, tuffs are intermediate between flood basalts and rhyodacites, except $\mathrm{Mg}$ is similar to that of basalt and tuffs have elevated $\mathrm{LOI}, \mathrm{B}, \mathrm{Cr}, \mathrm{Cs}, \mathrm{Cu}, \mathrm{Ni}$, and $\mathrm{Pb}$. The chlorophaeite sample (Mokrany-3A), when compared to its host basalt (Mokrany-3B), is 330 depleted in most elements, including HREE and Fe, $\mathrm{Na}, \mathrm{Ca}, \mathrm{Ba}, \mathrm{Sr}, \mathrm{Nb}, \mathrm{Sc}, \mathrm{Y}, \mathrm{Zn}, \mathrm{U}, \mathrm{V}$, and $331 \mathrm{Zr}$, but is strongly elevated in $\mathrm{Si}$ and moderately elevated in $\mathrm{Mg}, \mathrm{LOI}, \mathrm{Cr}, \mathrm{Cs}, \mathrm{Cu}, \mathrm{Ni}, \mathrm{Rb}$, and LREE. The vein clays, when compared to average basalt, have strongly elevated $\mathrm{Mg}, \mathrm{LOI}$, and $\mathrm{Co}$, elevated $\mathrm{Fe}, \mathrm{Ga}$ and $\mathrm{Ni}$, but most of the elements are depleted. REE are depleted

334 particularly strongly and several times stronger in chlorite (Kob-23) than in the trioctahedral 335 smectite sample (4600-1). The clay fraction of the latter is depleted even stronger. When clay 336 fractions separated from basalts are compared to their host rocks, the common characteristics 337 are the clay enrichment in $\mathrm{Mg}, \mathrm{LOI}, \mathrm{Be}, \mathrm{Co}, \mathrm{Cr}, \mathrm{Mo}$, and $\mathrm{Ni}$, and depletion in $\mathrm{B}, \mathrm{K}, \mathrm{Ca}, \mathrm{Sr}$, $338 \mathrm{Ba}, \mathrm{Ti}, \mathrm{Cu}, \mathrm{Nb}$, and $\mathrm{V}$. REE contents of the basalt clay fractions do not differ significantly 339 from the bulk rock contents.

\section{Mössbauer data}

343 The Mössbauer data (Table 1) were collected for a range of bulk rock basalt, vein clay, and 344 tuff samples, selected clay fractions $<0.2 \mu \mathrm{m}$, and two pyroxenes separated from the basalts. 345 The spectra of pure minerals separated from basalts were used as starting parameters for 346 fitting polymineral spectra of rocks (Table 1, Figure 4) and include: trioctahedral smectite 347 (Inline Supplementary Figure 5, 4600-1), dioctahedral smectite (4529-2, cf. Liivamägi et al., 
2018), chlorite (Figure 4, Kob-23), and pyroxenes (4519-0 and 4603-1). Where applicable,

349 the well known sextet of hematite and two sextets of magnetite were included in the fit.

Chlorite was found to contain only $\mathrm{Fe}^{2+}$, dioctahedral smectite only $\mathrm{Fe}^{3+}$, and trioctahedral smectite both $\mathrm{Fe}^{2+}$ and $\mathrm{Fe}^{3+}$. Two pyroxenes contained $\mathrm{Fe}^{2+}$ distributed over two possible crystallographic positions in different proportions, visible in the Mössbauer spectra as two well resolved quadrupole doublets. Finally, the rocks were analyzed assuming up to 7

354 different components with 9 subspectra (Table 1, Figure 4). In sample Mokrany-1B one additional component was detected with parameters characteristic of the amorphous wüstite, $356 \mathrm{FeO}$.

The measured bulk rock percent $\mathrm{Fe}^{2+}$ in the total $\mathrm{Fe}$ vary from 65 to $23 \%$ for flood 358 basalts and from 49 to $11 \%$ for tuffs. The corresponding $\mathrm{Fe}^{2+}$ values, calculated for the clay 359 fraction from the bulk rock data, are lower than the bulk rock values for less altered flood 360 basalts but higher than the bulk rock values for more altered basalts and tuffs. The $\% \mathrm{Fe}^{2+}$ 361 values of clays, measured for the $<0.2 \mu \mathrm{m}$ fractions and calculated from the bulk rock analysis 362 are essentially identical, if no chlorite or chlorite-smectite is present (Mokrany-3B and 4504-1 363 in Table 1), indicating that the separation procedure did not affect the oxidation status of Fe in 364 smectites. The $\% \mathrm{Fe}^{2+}$ values are lower in the bulk rock in other cases (4417-1 and 4600-1), 365 which is explained by relative concentration of smectite with respect to chlorite in the $<0.2$ $366 \mu \mathrm{m}$ fraction.

\section{FTIR data}

\section{Identification of clay fractions}

371 The mid-infrared (MIR) spectra of the <0.2 um fractions of XRD-identified end-member 372 components (dioctahedral smectite from paleosol 4517-1, trioctahedral smectite from 4600-1, 
and chlorite from Kob-23) were measured to serve as references (Figure 5). Spectra appear similar in the $\mathrm{vOH}$ region, exhibiting two broad bands centered at $3624 \mathrm{~cm}^{-1}$ due to smectite or chlorite structural $\mathrm{OH}$, and at $3434 \mathrm{~cm}^{-1}$, mainly due to water. For chlorite, the band at $3624 \mathrm{~cm}^{-1}$ is characteristically broader than for the other samples and is typical of trioctahedral chlorite (clinochlore type). For the dioctahedral smectite, the $3624 \mathrm{~cm}^{-1}$ is characteristically narrower than for the other samples and is typical of montmorillonite (e.g. Madejová et al., 2017). For the trioctahedral smectite (4600-1), a shoulder at about $3670 \mathrm{~cm}^{-1}$ is observed in addition to the $3624 \mathrm{~cm}^{-1}$ band. Such bands are found in griffithite (Madejová et al., 2017), which was previously identified as a trioctahedral iron-rich saponite (Komadel et al., 2000). Note that for saponite depleted in iron, the $v O H$ is narrow and centered at $3678 \mathrm{~cm}^{-}$ 1. The spectra of the two other samples Mokrany-3B and 4504-1A are similar to 4600-1.

The 1200-400 $\mathrm{cm}^{-1}$ region was more discriminant for sample characterization. The dioctahedral smectite could be unambiguously identified as montmorillonite through the occurrence of $\delta \mathrm{Al}_{2} \mathrm{OH}$ and $\delta \mathrm{AlMgOH}$ specific vibration bands at 920 and $837 \mathrm{~cm}^{-1}$, respectively (e.g. Madejová et al., 2017). A shoulder at $878 \mathrm{~cm}^{-1}$ due to $\delta \mathrm{AlFe}^{3+} \mathrm{OH}$ indicated that the montmorillonite contains some octahedral trivalent iron. The spectra of the 4600-1 and 4504-1A samples corresponded clearly to griffithite with the characteristic bands at 1016, 678 and $452 \mathrm{~cm}^{-1}$ and shoulders at 740 and $520 \mathrm{~cm}^{-1}$ (Madejová et al., 2017). The two strong bands at 1016 and $452 \mathrm{~cm}^{-1}$ are respectively due to $\delta \mathrm{Si}-\mathrm{O}$ and $\delta \mathrm{Si}-\mathrm{O}$, whereas the $678 \mathrm{~cm}^{-1}$ band is mainly due to $\delta\left(\mathrm{Fe}^{2+}, \mathrm{Mg}\right)_{3} \mathrm{OH}$ and indicates clearly the trioctahedral nature of the smectite. The Mokrany-3B spectrum revealed quartz in mixture with griffithite. The small shoulders at 876 and $912 \mathrm{~cm}^{-1}$ indicated the occurrence of octahedral aluminium and trivalent iron in dioctahedral configuration.

\section{Comparison between clay component in chlorophaeite and the surrounding basalt}


As seen in Figure 6, the clay components in chlorophaeite are the same as those in the 399 surrounding basalt. Indeed, for Mokrany-3A and Mokrany-4A, the spectra revealed the same 400 features as for Mokrany-3B described above. The clay component is then griffithite (see 401 above). The slightly more pronounced dioctahedral features (shoulders at 878 and $912 \mathrm{~cm}^{-1}$ 402 due to of $\delta \mathrm{Al}_{2} \mathrm{OH}$ and $\left.\delta \mathrm{AlFe}^{3+} \mathrm{OH}\right)$ in Mokrany-4A indicated a higher content of octahedral 403 aluminium and trivalent iron in dioctahedral configuration than in Mokrany-3A. For 404 Mokrany-1A, the difference between the two spectra was the occurrence of feldspars in the surrounding basalt that hide the clay component features. However, in both samples griffithite could be identified and no dioctahedral features could be observed. The variability of chloropheite composition detected in MIR was also well expressed in NIR (near infrared), where the clay features could be observed without overlapping by quartz or feldspars.

\section{Organic geochemistry data}

All the rock samples investigated in this study contain organic matter (OM), but total organic

413 carbon (TOC) content did not exceed $0.2 \%$. The main constituents of OM in silylated total 414 extracts (Figure 7A) were $n$-alkanes and fatty acids (FAs). The distribution of these 415 biomarkers in the basalt sample 4600-3B differs significantly from other samples (Figure 7B): 416 long-chain $n$-alkanes and $n$-alkanoic acids with the maxima between $\mathrm{C}_{23}$ and $\mathrm{C}_{29}$, and $\mathrm{C}_{22}$ and $417 \mathrm{C}_{30}$ carbon atoms, respectively, are present in relatively high concentrations. The values of 418 short-chain to long-chain ratio ( $\mathrm{SCh} / \mathrm{LCh})$ for $n$-alkanes and FAs for $4600-3 \mathrm{~B}$ are 2.64 and 419 1.27, respectively, whereas they are 9.12 and 29.81 for $4600-3 \mathrm{~A}$. Moreover, OM in sample 4600-3B is characterized by the predominance of high molecular weight odd-carbon421 numbered $n$-alkanes and even-carbon-numbered FAs, with the carbon preference index (CPI) 422 values of $1.70\left(\mathrm{CPI}_{(25-31)}\right)$ and $1.30\left(\mathrm{CPI}_{\text {total }}\right)$ for n-alkanes, and $7.43\left(\mathrm{CPI}_{\text {f.a.(20-30) }}\right)$ for FAs (for 
423 CPI formulas see Rybicki et al., 2016). In the clay sample 4600-3A such predominance is not

424 evident $\left(\mathrm{CPI}_{(25-31)}=1.01\right.$ and $\left.\mathrm{CPI}_{\text {total }}=0.83\right)$.

Alteration petrography of chlorophaeite-bearing flood basalts

The primary components of basaltic rocks identified by the petrographic observations are pyroxenes (ortho- and clinopyroxene), $\mathrm{Ca}-\mathrm{Na}$ plagioclases, $\mathrm{Fe}, \mathrm{Ti}$ oxides (titanomagnetite and ilmenite) and a homogeneous orange-brown isotropic substance presenting all the characteristics of chlorophaeite, as identified in several basaltic fields (Peacock and Fuller, 1928). Such isotropic material occurs in several petrographic settings: (1) areas of intersertal mesostasis through the body of the basaltic rocks (Figure 8A), (2) filling or lining of circular cavities (Figure 8B), (3) veinlets and associated infilling of dixitaxitic voids in the basaltic rock (Figure 8C), (4) pseudomorphs after orthopyroxene (Figure 8D).

In the least altered basalts (sample 4522-1), chlorophaeite is totally isotropic at a microscopic scale and it contains fine networks of minute cracks, which tend to be more developed when observed under vacuum (evidence of water content). In the cavities, chlorophaeite occurs as irregular films showing frequently collomorphous texture typical of precipitation of a gel material (Figure 8B). chemical homogeneity (Table 2). The sum of oxide weight percent, which does not exceed $85 \%$, indicates a high water content of this isotropic material. Silicon and iron ( oxidation 444 state not determined from $\mathrm{EDS}$ ) are dominant, with subordinate $\mathrm{Mg}, \mathrm{Al}$ and $\mathrm{Ca}$, and minor amounts of alkali elements $(\mathrm{Na}, \mathrm{K})$. Such a composition reasonably agrees with the formula

446 given by Peacock and Fuller (1928) for chlorophaeite: $(\mathrm{Fe}, \mathrm{Al})_{2} \mathrm{O}_{3} \cdot 2(\mathrm{Mg}, \mathrm{Fe}, \mathrm{Ca}) \mathrm{O} .4 \mathrm{SiO}_{2}+$ $447 \quad 10 \mathrm{H}_{2} \mathrm{O}$. 
449 after the crystallization of quartz on the walls of vesicles and before the crystallization of 450 chlorite, which cements the central parts of the vesicles. In the absence of phyllosilicates, 451 minerals of the zeolite group are commonly observed as the late mineral cement of the 452 residual open spaces of the basaltic rocks.

Smectitic clayswere observed systematically as alteration products of the 454 chlorophaeite bearing basaltic rocks. In the less altered basalts (sample 4522-1), the occurrences of smectitic clays are limited to minute spherules replacing chlorophaeite close to the contacts with the primary minerals of basalt (Figure 8E). Detailed observations with SEM indicate that such spherules are alteration features of chlorophaeite with a typical concentric structure. Smectitic clays, rimmed by a thin iron rich layer, were observed in the inner part of the spherule. The transition to unaltered chlorophaeite is marked by an external alteration halo, due to increasing microporosity and/or hydration of the initial isotropic material (Figure $8 \mathrm{~F})$.

Chemical microanalysis of smectitic clays formed in the spherules indicates a close chemical similarity with that of the chlorophaeite starting material, except for lower iron and higher $\mathrm{Mg}$ and $\mathrm{Al}$ in the smectite (Table 2). The thin iron rich layer of the spherules likely accommodates the excess iron released during the alteration process of chlorophaeite. optical characteristics because of replacement by spherulitic and ribbon-like smectitic clays.

468 Furthermore, primary or the previously formed hydrothermal minerals present features of 469 partial dissolution. This is particularly the case for the iron rich phyllosilicates such as Fechlorite (Figure $8 \mathrm{G}$ ). It should be noted that quartz presents also some evidence of dissolution 471 at the contact with the smectitic clays (Figure $8 \mathrm{H}$ ). In strongly argillized samples (4603-1, and 
4603-4), chlorophaeite is totally replaced by smectitic clays and the basaltic primary minerals are partially replaced by smectitic clays and minerals of the zeolite group.

\section{$\mathrm{O}$ and $\mathrm{Fe}$ isotope data}

Oxygen isotope data were collected for a range of bulk basalts showing variable alteration intensity, for a few clay vein and tuff samples, and for selected clay fractions $<0.2 \mu \mathrm{m}$ (Table 1). The least altered basaltic rocks have oxygen isotope values of 5.6 to $8.4 \%$. Basalts with increasing amount of alteration as well as tuffs have elevated $\delta^{18} \mathrm{O}$ values ranging from 10.1 to $20.0 \%$, similar to the isotope range of clay separates (17.8 to $21.0 \%$ o), and green clays from veins and cavities (10.1 to $17.0 \%$ ). The paleosol samples have elevated oxygen isotope values of 21.3 to $21.7 \%$ and the chlorophaeite sample has the highest measured value of 23.0 $\%$.

A few of these $<0.2 \mu \mathrm{m}$ clay fractions were also analyzed for iron isotope compositions (Table 1). In moderately altered basalts, the measured $\delta^{56} \mathrm{Fe}$ values are positive (0.028 for Mokrany-3B), but become negative with increasing alteration (down to -0.574 for Kob-23).

\section{K-Ar dating of aluminoceladonite and illite-smectite}

Selected 2-0.2 and $<0.2 \mu \mathrm{m}$ fractions of tuffs containing aluminoceladonite and illite-smectite were dated, at least twice, in order to establish the age of potassic alteration (Table 3). The $\mathrm{K}_{2} \mathrm{O}$ contents vary from $1.785 \%$ for the sample Tashki-10, with minor amounts of aluminoceladonite and illite-smectite, to $6.71 \%$ for Kob-9B, dominated by aluminoceladonite 
496 (comp. Inline Supplementary Figure 4). The measured ages range from $447.5 \pm 2.5$ to $296.0 \pm 5$

497 Ma.

Interpretation

Alteration of flood basalts

502

\section{$\underline{\text { Mineral changes }}$}

No single sample was identified by XRD to be composed exclusively of primary basalt minerals: Ca-plagioclase, pyroxene, magnetite, ilmenite, and pseudobrookite. All samples contain hydrated components (mostly clays), but in variable quantities. If the sum of primary basalt minerals is accepted as an inverse index of basalt alteration, and if the degree of alteration is interpreted as a chronosequence (stronger alteration considered as a subsequent step of the process), a clear pattern of basalt alteration emerges, which can be described by

five steps (Inline Supplementary Table 1), leading from almost fresh basalt to completely 511 altered rock, though still preserving the basalt texture. In the investigated samples, the earliest alteration products are quartz with trioctahedral smectite, or with a mixture of di- and trioctahedral smectite, all together $<10$ basalts with more advanced alteration (compare Mokrany samples in Inline Supplementary

516 Table 1). Based on this identity and on the microscope observations, we assume that the early 517 quartz did not crystallize from melt but it is a product of basalt alteration (mostly of volcanic 518 glass), deposited in crystal interstices or in larger chlorophaeite accumulations. Thus, step I can be identified tentatively as predominantly the alteration of volcanic glass. Emetz et al. (2006) also identified quartz as an alteration mineral based on petrographic observations. 
In step II (90-80 \% primary minerals), orthoclase/sanidine and hematite appear and

522 the amount of smectites increases compared to step I. In step III (80-60\% primary minerals), chlorite appears, hematite, quartz and smectite abundances increase, pyroxene decreases, and ilmenite is absent. In step IV (60-25\% primary minerals), anatase, analcime, zeolites and calcite appear, smectite, quartz and orthoclase/sanidine increase further, plagioclase starts decreasing, and pyroxene and pseudobrookite disappear. In step V ( $<25 \%$ primary minerals), plagioclase and magnetite disappear, and dioctahedral smectite plus chlorite prevail over trioctahedral smectite. The mineral composition of green clay veins and cavities in basalts is similar to the most altered basalts of step V. Ubiquitous hematite indicates an oxidizing alteration environment. In general, the lower basalts appear more altered than the upper basalts. Petrographic study confirmed the crystallization of smectite both before and after chlorite.

\section{Chemical changes}

The mineral alteration of basalt is paralleled by characteristic chemical changes, which are surprisingly limited (Inline Supplementary Table 4) considering the extent of alteration observed in some samples. The most pronounced is the decrease of $\mathrm{CaO}$ from $10 \%$ almost to $0 \%$ (except of samples with abundant calcite). The progressing dissolution of Ca-plagioclase results in the removal of Ca from the system (Inline Supplementary Figure 6). Sr decreases along with Ca. In steps IV and V, when plagioclase decreases strongly and analcime and other zeolites appear, Na seems to undergo redistribution: it is depleted from rocks without zeolites and enriched in remaining rocks.

The most pronounced gain during basalt alteration is the sum of $\mathrm{OH}$ and $\mathrm{H}_{2} \mathrm{O}$ in clays, represented by the loss on ignition (LOI), which increases from almost $0 \%$ to $6.5 \%$ in samples free of calcite. The correlation of sum of clay with LOI is very high and extrapolates to 0 for 
unaltered basalt and to $9 \%$ for completely altered basalt. The trend line runs between values

547 characterizing smectitic and chloritic green clay veins in basalt (Figure 9), in agreement with 548 the intermediate, smectite+chlorite composition of clays in strongly altered basalt. LOI can 549 serve as a simple measure of the degree of basalt alteration.

In the course of alteration, basalts also gain $\mathrm{MgO}$, which increases about two times: from 5 to $10 \%$ and is positively correlated with the sum of clays (Figure 9), except of the samples with carbonates (not shown in the figure). Boron increases even more, in particular in steps IV and V, and good positive correlation indicates that $\mathrm{B}$ is located in the dioctahedral clay (Inline Supplementary Figure 7). Some increase in K, Cs, and Rb is also observed, and these trends can be best explained by combined contributions from K-spar and dioctahedral clay (Inline Supplementary Figure 8), which is partially illitized during much younger Paleozoic events (see below), particularly in highly altered basalts (Inline Supplementary Table 3).

The remaining elements vary, but no trends related to the degree of alteration can be observed (Inline Supplementary Table 4). The mass of basalt during alteration essentially does not change, because the additions and subtractions of elements quantitatively compensate. This mass stability is best expressed by very stable $\mathrm{SiO}_{2}$ and $\mathrm{Al}_{2} \mathrm{O}_{3}$ contents. The collected data do not indicate measurable chemical changes between the lower and upper flood basalts.

REE patterns of most basalt samples are very similar and characteristic of the continental flood basalts (Farmer, 2003): enriched in LREE and without an Eu anomaly (Figure 10). REE do not differentiate the lower from the upper basalts. LREE seem slightly depleted at the final alteration step, particularly in the rock with high chlorite content (Kob22), but otherwise basalt alteration does not affect the REE pattern, despite sometimes total destruction of major primary minerals. Inline Supplementary Figure 9 indicates that LREE in 
basalts seem mostly contained in phosphates, of too low content to be detectable mineralogically (Inline Supplementary Table 1). In chlorophaeite, LREE are strongly concentrated, compared to regular basalts, while

HREE are depleted, and a strong negative Eu anomaly is present (Mokrany-3A in Figure 10 and Inline Supplementary Figure 9). This composition confirms the origin of chlorophaeite from the volcanic glass, enriched in incompatible LREE, while depleted in Eu contained in plagioclase (Weill and Drake, 1973) and depleted in HREE, which form isomorphic substitutions in pyroxene (Rollinson, 1994; Kuzmenkova, 2009). The basalt sample hosting chlorophaeite concentrations (Mokrany 3B in Figure 10 and Inline Supplementary Figure 9) displays analogous characteristics. Both have much higher $\mathrm{LREE} / \mathrm{P}_{2} \mathrm{O}_{5}$ ratio compared to regular basalts (Inline Supplementary Figure 9). These characteristics are similar to rhyodacite samples, which also differ from basalts by elevated LREE, negative Eu anomaly (Figure 10), and much higher LREE/ $\mathrm{P}_{2} \mathrm{O}_{5}$ ratio (Inline Supplementary Figure 9).

\section{Oxygen isotopes and $\mathrm{Fe}^{2+} / \mathrm{Fe}^{3+}$ ratio}

The progress of basalt alteration can be traced also by oxygen isotope compositions of the bulk rock samples (Table 1, Figure 11). They evolve linearly and extrapolate to a value close to $5 \%$ for the unaltered protolith, consistent with the oxygen isotope composition of unaltered continental flood basalts that show little to no contamination by continental crustal material (e.g. Harmon and Hoefs, 1995; Eiler 2001), and to the value of about 22\%o for complete alteration, similar to the isotopic compositions of smectite from the weathering zone (4529-2 and 4517-1) developed on basalts. A similar value of $23 \%$ characterizes the measured chlorophaeite sample, composed exclusively of secondary minerals (Mokrany-3A) and the clay fraction separated from the host basalt (Mokrany-3B<0.2). In Figure 12, the equilibrium relationships between oxygen isotope composition of smectite, of water, and temperature, 
596 based on the fractionation equation of Sheppard and Gilg (1996) are depicted. The smectite597 rich paleosol samples are in equilibrium with waters of about $-5 \%$ at ambient temperatures. 598 Using this isotope value of meteoric water, temperatures of dioctahedral smectite alteration in 599 the basalts is estimated at less than $40^{\circ} \mathrm{C}$. On the other extreme, if only magmatic water with a 600 heavy oxygen isotope composition of $+5 \%$ is assumed as the clay-forming fluid, then 601 temperatures of about 100 to $130^{\circ} \mathrm{C}$ are indicated for the dioctahedral smectite formation. Another parameter correlating well with the applied index of basalt alteration is \% $603 \mathrm{Fe}^{2+}$ of the bulk rock measured by Mössbauer spectroscopy (Table 1, Figure 13). The only 604 measured chlorophaeite sample also fits this trend (Mokrany-3A). The linear trend 605 extrapolates to ca. $67 \%$ for pure basalts and falls to $30 \%$ at ca. $40 \%$ of primary minerals, 606 where those containing $\mathrm{Fe}$ almost disappear. $\mathrm{Fe}^{2+}$ was lost due to oxidation, and not removal 607 under anoxic conditions, as Fe content of the rock remained stable (Inline Supplementary 608 Table 4). This trend implies that basalt alteration from the very beginning involved water 609 carrying oxygen, in agreement with the increasing content of hematite.

610 The most altered samples (Kob-15 and 4417-1) and green clays from veins and 611 cavities (4600-1 and Kob-23) fall off the general trend, as their $\% \mathrm{Fe}^{2+}$ is much higher (Table

612 1, Figure 13). This implies higher $\% \mathrm{Fe}^{2+}$ of clays at this stage of alteration, which agrees well with the Mössbauer estimates of $\% \mathrm{Fe}^{2+}$ in clay fractions of rocks (Figure 13), the Mössbauer 614 data for tuffs, and the abundance of chlorite in these rocks. These data lead to the conclusion 615 that at the most advanced stage of alteration, the conditions became more reducing.

\section{$617 \quad$ Alteration of organic compounds}

618 The primary distribution of particular organic compounds depends on the source of OM and 619 can be modified by a wide range of post-depositional processes. Algae and bacteria generate 620 short-chain $n$-alkanes with preponderance of $\mathrm{C}_{17}$ and $\mathrm{C}_{19}$ carbon atoms in the molecule, while 
621 terrestrial higher plants (especially their leaf epicuticular waxes) are characterized by the 622 occurrence of long-chain $n$-alkanes and $n$-fatty acids ( $n$-FAs). Our studies evidenced a clear 623 predominance of long-chain $n$-alkanes and $n$-FAs (excluding $\mathrm{C}_{16}$ and $\mathrm{C}_{18}$ ) with majority of an 624 odd and even number carbon atoms in the molecules, respectively, in most of the Ediacaran 625 sedimentary rocks from the EEC (Goryl and Marynowski, 2016). Bobrovskiy et al. (2018) 626 suggested that a possible source of long-chain $n$-alkanes in the Ediacaran rocks are spherical 627 cyanobacterial colonies. The level of thermal maturity of the Ediacaran OM from the EEC is 628 unusually low (the estimated equivalent of vitrinite reflectance did not exceed $0.57 \% \mathrm{Rr}$ ) 629 which promoted preservation of the primary character of distribution of organic compounds 630 (Pehr et al., 2018; Goryl et al., 2018).

631 We believe that OM from the basalt sample 4600-3B is the most primary, non632 oxidized or only slightly oxidized remnant of the Ediacaran cyanobacteria (and other 633 microorganisms?) activity in the basalt hydrothermal system. Decay of long-chain $n$-alkanes 634 and $n$-FAs and decreasing value of CPI in all other samples indicate more intense oxidation of $635 \mathrm{OM}$ in paleosols and in clays from cavities. Similar effect of OM alteration was presented by 636 Elie et al. (2000, 2004): gradual degradation of long-chain $n$-alkanes and $n$-alkanoic acids 637 during artificial oxidation of argillaceous rocks. Also Marynowski and Wyszomirski (2008) 638 presented significant influence of early diagenetic oxidation on $n$-alkanes and other organic 639 compounds distribution on an example of green and red Triassic clays. It seems that in the 640 basaltic rock, primary OM was better protected against oxidation by the Ediacaran 641 hydrothermal processes and further Caledonian and/or Variscan alterations. Such 642 cyanobacteria activity offers a feasible explanation of more reducing conditions observed at 643 the final stages of basalt alteration.

\section{Characteristics of the basaltic smectite}


For three available pure smectitic samples $(<0.2 \mu \mathrm{m}$ fractions $)$ with variable ratios of di- and trioctahedral components, the chemical data (Inline Supplementary Table 4), including $\mathrm{Fe}^{2+} / \mathrm{Fe}^{3+}$ ratio from the Mössbauer spectroscopy (Table 1), were cast into structural formulae (Table 4). The amount of potassium is very low, consistent with the XRD characteristics (Inline Supplementary Table 3, Inline Supplementary Figure 2). The chemical compositions of the three smectitic samples evolve in a regular manner, consistent with the XRD evaluation of di/tri-smectite ratio (Table 4). The calculated numbers of octahedral cations are between 2 and 3 per half unit cell and they can be used as a measure of di/tri-smectite ratio. Plots of other data with respect to these numbers are linear $\left(\mathrm{R}^{2}=0.92\right.$ 649 0.99) and allow extrapolating compositions of the end member components (Table 5). The 650 dioctahedral smectite end member is a perfect montmorillonite without tetrahedral substitution, high Fe and $\mathrm{Mg}$ contents, and no divalent iron, as confirmed by Mössbauer spectra of the dioctahedral smectite component (Table 1) and dioctahedral smectite identified from basalt weathering zones by Liivamägi et al. (2018). Its oxygen isotope characteristics and its positive $\mathrm{d}^{56} \mathrm{Fe}$ are also similar to the montmorillonites from paleosols, which are however much more rich in $\mathrm{Al}$ (op. cit.). The dioctahedral smectite has been partially illitized during the Paleozoic thermal events (see below).

Almost all REE is contained in the dioctahedral clay, which is consistent with their trivalent character (the dioctahedral sheet accepts mostly trivalent cations). Exceptionally low 659 REE content of chlorite Kob-23 (Figure 10), which contains 95\% of divalent iron (Table 1) is 660 consistent with this interpretation of REE segregation. Thus dioctahedral clays are partially 661 responsible, along with phosphates, for the REE budget of the investigated rocks. This conclusion is confirmed by $\mathrm{P}_{2} \mathrm{O}_{5}$ depletion in clay fractions compared to the bulk rock (Inline

663 Supplementary Table 4), parallel to the LREE enrichment in the clay fraction with dominant 664 dioctahedral component (Mokrany-3B). REE seem to be incorporated in the dioctahedral clay 
665

666

structure and not adsorbed like in weathering clays (Bau, 1991), as the clay fractions were analyzed after Na-exchange. The location of REE in clay structure indicates that they became available at the time of clay crystallization and not later. Otherwise they would occupy the exchange sites.

The trioctahedral smectite end member is almost ideal iron-rich saponite, with 0.84 $\mathrm{Al}^{\mathrm{IV}}$, no $\mathrm{Al}^{\mathrm{VI}}$, very high $\mathrm{Mg}$, and $\mathrm{Fe}$ not much higher than in the dioctahedral clay, but ferrous in $42 \%$. Its $\delta^{18} \mathrm{O}$ value is much lower than in di-smectite and its $\delta^{56} \mathrm{Fe}$ is negative, like in chloritic trioctahedral clays (Table 1).

XRD, chemistry and FTIR data are consistent and detect variable di/tri ratio of the investigated basaltic smectites. Based on the XRD evidence (separate 02 and 06 reflections) and very different REE contents and oxygen and iron isotope ratios, the smectitic clay component of Volyn basalts is interpreted here not as a mineral but as a mixture of iron-rich montmorillonite and iron-rich saponite. This mineral mixture occurs both in basalts and in the chlorophaeite accumulations (Figure 3 and Inline Supplementary Figure 3). A similar material was identified by Faust (1955), Ross (1960), and Komadel et al. (2000) as iron ditrioctahedral saponite, and named griffithite. Formulae of griffithite calculated from Ross (1960) and Komadel et al. (2000) data (Table 4) and the XRD data, obtained for Komadel et al. (2000) sample (Inline Supplementary Figure 3), suggest that it is also a mineral mixture, close to our sample 4600-1. The reported griffithite formulae differ strongly in the degree of iron oxidation, which may reflect sample heterogeneity and/or the measurement technique. Both samples come from the same original griffithite locality at Griffith Park in California, but may represent slightly different material. Other samples from this area are end-member Fe-saponites with high $\mathrm{Fe}^{3+} / \mathrm{Fe}^{2+}$ ratios (Treiman et al., 2014).

Very similar materials, named oxysmectites, were described by Dainyak et al. (1981) and Simanovich et al. (2010) from continental flood basalts of Siberia (Table 4) and from an 
690

691

692

693

694

oceanic basalt sample. The continental sample has di/tri ratio close to our 4504-1 but it has more Fe than Mg. A pure trioctahedral analogue of our sample 4600-1, but with Fe dominant over Mg (Table 4), was identified in a Siberian hydrothermal deposit and called ferrosaponite (Chukanov et al., 2004), the name accepted by IMA (Jambor and Roberts, 2004). Numerous occurrences of similar materials were reviewed by Sarkar et al. (2016), who identified ferrosaponite in continental basalts.

The relative enrichment of montmorillonite in the heavy Fe isotope compared to Fesaponite is consistent with the general rule that the oxidized form of Fe is enriched in heavy isotopes (Teutsch et al., 2009 and literature cited). Negative $\delta^{56} \mathrm{Fe}$ values of chloritic samples (Table 1), which contain only $\mathrm{Fe}^{2+}$, support this interpretation. Comparable or even higher fractionations of iron have been observed during oceanic basalt alteration and interpreted as abiotic (Rouxel et al., 2003), though a biotic involvement cannot be excluded in our case, as the dissimilatory iron reduction is regarded as the most efficient mechanism for generating isotopically light $\mathrm{Fe}^{2+}$ (Wu et al., 2010), and the presence of unaltered organic matter in basalt has been documented in previous sections.

Major differences in $\delta^{18} \mathrm{O}$ values between di- and trioctahedral smectite could be related to formation from the same fluid at different temperatures with trioctahedral smectite forming at ca. $50^{\circ} \mathrm{C}$ higher temperatures if fractionation factors are similar (Figure 12). However, theoretical considerations (Savin and Lee, 1988; Kohn and Valley, 1998) and empirical data (Craw et al., 1995) suggest that oxygen isotope fractionation between smectite and water is about $5 \%$ smaller for Mg-rich smectite than for Al-rich smectite. Thus, di-and trioctahdral smectites may have formed at similar temperatures and from the same fluid. On the other hand, the temperature difference may have been higher, if trioctahedral smectites formed from a fluid with magmatic component (isotopically heavier). 
715 product of isotropic material, which was described earlier in many publications under the 716 name "chlorophaeite". It was deposited during hydrothermal processes, cementing 717 successively the residual open spaces of the basaltic rocks. Under the microscope 718 chlorophaeite appears isotropic only in the least altered rocks, and during progressing 719 alteration it gradually evolves into birefringent smectite. This alteration is almost isochemical, 720 but some iron is lost (Table 2). In XRD, smectite from the chlorophaeite accumulation in least 721 altered basalt differs from others by more trioctahedral character and much smaller crystal 722 thickness, evidenced by more diffuse 001 reflection (Figure 3). NIR spectra indicate that it is 723 richer in $\mathrm{Fe}$, without detectable $\mathrm{Al}$ contribution. Combining these observations, we suggest 724 that the isotropic substance is a trioctahedral smectite close to ferrosaponite, with extremely 725 fine crystal size, which results in the isotropic characteristics. It may have been deposited originally as an amorphous material, but no clear evidence of such material was found in the 727 investigated samples. Smectite crystallizing from an amorphous material is known to form 728 originally extremely thin, even monolayer crystals (Derkowski et al., 2015 and references 729 therein). In the course of further alteration, ferrosaponite alters into a mixture of $\mathrm{Fe}$ 730 montmorillonite and Fe-saponite with well-developed multi-layer crystallites. At early stages, 731 the quantities of both smectites grow in parallel in the course of progressing alteration, but 732 trioctahedral smectites grow at twice higher rate (Inline Supplementary Figure 10). Latter, the 733 content of dioctahedral smectites continue to grow steadily, while the content of trioctahedral 734 smectites levels off and starts decreasing, when the hematite content starts increasing. We 735 interpret these relationships as indicative of the redox control over the process: as long as the 736 conditions are relatively reducing, crystallization of trioctahedral smectite is favored, both by 737 abundant $\mathrm{Mg}^{2+}$ and $\mathrm{Fe}^{2+}$ : the major constituents of the trioctahedral sheet. When $\mathrm{Fe}^{3+}$ becomes 738 dominant, the crystallization of dioctahedral smectite is favored (trivalent ions dominant in 
the dioctahedral sheet), and the decrease of trioctahedral smectite indicates that it is altered

740 into chlorite and/or dioctahedral smectite at these advanced stages of basalt alteration.

\section{$742 \quad$ Alteration of tuffs}

\section{Mineral changes}

745 Mineralogically, tuffs (volcano-clastic rocks) differ strongly from flood basalts by their much

746 broader range of quartz content, which, if elevated above basalt values, is always higher than

747 K-feldspar content. The opposite relation, characteristic of flood basalts, is common in low

748 quartz tuffs. If \% quartz is plotted against \% Kspar for all tuff samples (Inline Supplementary

749 Figure 11) it becomes clear that the tuffs have a broad range of intermediate compositions,

750 extending from basalts to the felsic rocks. Quartz content was used then as a proxy for this

751 primary tuff mineral variability (Inline Supplementary Table 2), and tuffs were divided into

752 samples close to basaltic composition (quartz <14\%) and more felsic samples. In general,

753 tuffs with $>20 \%$ quartz are competent rocks and with lower content of quartz are friable.

754 The basaltic tuffs resemble by mineral composition the most altered flood basalts:

755 some plagioclase still present in some samples, pyroxene and other primary minerals are 756 absent, anatase is present, hematite, di- and trioctahedral smectite plus chlorite are abundant,

757 and analcime is occasionally present. The apparent differences are the presence of albite and 758 aluminoceladonite.

The felsic tuffs seem less altered because their calcic plagioclase content is much

760 higher. They contain less anatase, hematite, trioctahedral smectite and chlorite. Only 761 dioctahedral clay is as abundant as in basaltic tuffs, but more illitized. They also contain

762 aluminoceladonite, but no albite or analcime. Kaolinite detected in the top samples of two 
Kobryn tuffs are indicative of subaerial weathering and soil development before deposition of

764 subsequent lava flows.

\section{$\underline{\text { Chemical changes }}$}

767 The arrangement of tuff samples by \% quartz reveals very clear trends in their chemical

768 composition (Inline Supplementary Table 4). Towards the basaltic end, Si and K contents decrease to a level typical of basalt, while Fe, $\mathrm{Al}, \mathrm{Mn}, \mathrm{Mg}$, Ti and LOI increase. $\mathrm{Mg}$ and LOI increase to the level characteristic for the most altered basalts, which is consistent with the mineralogical evidence. Among trace elements REE, Be, Ba, Cs, Nb, Rb, Sr, Ta, Th, U, Y, and $\mathrm{Zr}$ decrease, while $\mathrm{Co}, \mathrm{Cr}, \mathrm{Cu}, \mathrm{Ni}, \mathrm{Sc}, \mathrm{V}$ and $\mathrm{Zn}$ increase. No measurable control of the trap stratigraphy (lower vs. upper basalts) over chemistry can be observed.

In accordance with these trends, average contents of most elements for tuffs are intermediate between values for flood basalts and rhyodacites, indicating that, like flood basalts, also tuffs were altered without a major change of mass. For a few elements, the averages for tuffs are higher than the end member values: $\mathrm{B}, \mathrm{Mg}, \mathrm{LOI}, \mathrm{Cr}, \mathrm{Cs}, \mathrm{Cu}, \mathrm{Ni}$, and $\mathrm{Pb}$. Such elevated values imply the import of these elements during alteration, similar to the detected in basalts (B, Mg, LOI, Cs) but including metals. Also in basalts metals are mobile, as recorded by the metals enrichment in chlorophaeite and clay fractions, as compared to their bulk basalt samples (Inline Supplementary Table 4). This conclusion is consistent with the observation of native copper and silver occurrences in association with chlorophaeite 783 (Kuzmenkova et al., 2006a). balance references in weathering studies (e.g. Liivamägi et al., 2018) are much less abundant in basalts than in felsic rocks. They differentiate the studied rocks similarly to quartz content (compare Inline Supplementary Figure 11and 12), confirming the classification of tuffs based 
on mineralogy into more basaltic and more felsic. In general, also this approach does not

789 differentiate lower from upper volcanics. Locally, subsequent levels of flood basalts and tuffs can be differentiated, as illustrated in Inline Supplementary Figure 13for Kobryn profile, where three levels of tuffs and two levels of flood basalts have been sampled over ca. $150 \mathrm{~m}$ 792 of depth. The tuff composition is clearly more felsic. On the other hand, four tuff samples 793 from Tashki plot in Inline Supplementary Figure 9 outside the basalt field, indicating an even 794 more basic composition than the available basalt samples. They represent bottom part of the 795 volcanic sequence, where picrites and picrobasalts were identified (Kuzmenkova et al., 2011; 796 Shumlyanskyy et al., 2016).

The tuffs vary in color in most profiles, alternating from green to brown and even red.

798 Green color is more common among more felsic tuffs. When compared with other tuffs of 799 similar quartz content, green tuffs differ from brown tuffs only by less hematite and more U, 800 which is consistent with more reducing local environment (evacuation of Fe, enrichment in $\mathrm{U}$ ) 801 but does not allow us to conclude whether this is a hydrothermal alteration feature or the 802 result of a younger process. The lack of systematic difference in clay composition favors the 803 latter explanation.

804

\section{Oxygen isotopes and $\mathrm{Fe}^{2+} / \mathrm{Fe}^{3+}$ ratio}

806 Both sets of data collected for tuffs of basaltic composition do not follow trends characteristic 807 of flood basalts and resemble data obtained for clay veins in basalts: $\mathrm{d}^{18} \mathrm{O}$ values are lower ( 808 Figure 11) and $\% \mathrm{Fe}^{2+}$ values are higher than extrapolations of basaltic trends to the zone of 809 complete alteration (comp. Table 1 with Figure 13). These relations can be explained by 810 higher abundance of chlorite in the analyzed tuff samples compared to the flood basalts 811 (Supplementary Table 1 and 2), based on the $\% \mathrm{Fe}^{2+}$ and the oxygen isotope data for Kob-23 812 chlorite (Table 1). 


\section{$814 \quad$ K-Ar dating of clay fractions}

815 Dates of replicate analyses and dates of two fractions all are within the error range for a given

816 sample, thus they can be regarded as representing unique illitization episodes (Środoń et al., 817 2002). In the south (Tashki), the Carboniferous date of ca. 300 Ma was obtained, while in the 818 north, dates range from 417 to $447 \mathrm{Ma}$. A very similar geographical distribution of ages was 819 detected by dating aluminoceladonite and illite-smectite in paleosols developed on basalts 820 (Liivamägi et al., 2018). Clearly, the potassic alteration episode affected tuffs and paleosols 821 developed on flood basalts long after the formation of these rocks. Basalts were also affected, 822 though to a lesser extent: aluminoceladonite was not formed, but smectite was slightly 823 illitized (Supplementary Table 3).

824

\section{Discussion and conclusions}

826

827 Flood basalts and tuffs of the Volyn-Brest province were affected to a very different extent by 828 two subsequent alteration episodes, the first pre-dating and the second post-dating the 829 Ediacaran weathering of top surface.

830 The first alteration episode involved sequential destruction of volcanic glass and

831 primary basaltic minerals and crystallization of secondary phases: tri- and dioctahedral 832 smectite, chlorite and/or mixed-layer chlorite-smectite, hematite, quartz, anatase, and zeolites. 833 Basalts which underwent Ediacaran weathering studied by Liivamägi et al. (2018) contained 834 such secondary mineral assemblage. The basaltic smectites are of unique composition: montmorillonite with high $\mathrm{Fe}^{3+}$ and 836 saponite also high in $\mathrm{Fe}$, but with significant $\mathrm{Fe}^{2+}$ content. Similar clays have been described 
earlier from various basalt provinces under the names "chlorophaeite", "griffithite" or "oxysmectite", and "ferrosaponite" if Fe>Mg.

The term "chlorophaeite" is used also in macroscopic descriptions to name accumulations of dark glassy matter in basalts. Such chlorophaeite accumulations do not contain primary basaltic minerals, but mainly secondary minerals characteristic of the first step of basalt alteration (quartz, tri- and dioctahedral smectite), also if chloreophaeite accumulations are contained in basalts of higher alteration step (Supplementary Table 1). In particular, they do not contain hematite, they are strongly enriched in $\mathrm{Si}$ and enriched in $\mathrm{Mg}$ and metals compared to the host basalt. These observations, along with the REE pattern, suggest that chlorophaeite accumulations are products of alteration of the amorphous material (solidified leftover melt, i.e. volcanic glass), in agreement with conclusions of many earlier researchers (Kuzmenkova et al., 2006b and the references cited), and that the alteration took place at the earliest stage, in non-oxidizing environment, but it is related to the same solutions that altered flood basalts and tuffs.

The subaerial location, the evolution of bulk rock $\mathrm{Fe}^{2+} / \mathrm{Fe}^{3+}$ measured by Mössbauer spectroscopy, the evolution of bulk rock oxygen isotope composition, the presence of hematite, and the lack of depletion in Fe and Mn indicate that the basalt alteration involved oxygenated meteoric waters, probably heated and put in motion by the cooling basalt flows. Such heat-driven convection of meteoric water is a very effective mechanism of alteration of cooling volcanic bodies (e.g. Eberl et al., 1987). A similar mechanism of alteration of Volyn flood basalts was proposed by Melnychuk (2006), who envisioned the Ediacaran dolerite sills intruding basalts and the underlying sandstones as the source of heat. The heat-driven convection mechanism explains well the observed major enrichment in $\mathrm{Mg}$, brought by upflow from deeper parts of the basalt body, where olivine and pyroxene are early subjects to alteration. The alteration sequence is analogous to these reported from other hydrothermal 
862

863

subaerial, hydrothermal submarine, and burial metamorphic alterations of basalts, including the difference in $\mathrm{Si} /(\mathrm{Si}+\mathrm{Al})$ and $\mathrm{Fe} /(\mathrm{Mg}+\mathrm{Fe})$ ratios between the smectitic and chloritic clays (Table 4). The alteration conditions were more oxidizing, which is manifested by the presence of hematite from early stages of the alteration process. A rare feature for the basalt alteration series is the abundant development of dioctahedral smectite, which continued later during the weathering stage, as documented by Liivamägi et al. (2018). The alteration proceeded from outside into the basalt layers, as observed also earlier (Juskowiakowa, 1974), and in extreme cases it was complete: all basaltic minerals were altered but the basalt texture was preserved. Our data indicate that microbial organisms participated in the hydrothermal alteration process, which is consistent with earlier evidence of the microbial life on the Ediacaran land in this area (Kremer et al., 2018; Liivamägi et al., 2018).

Compared to flood basalts, the alteration of tuffs of basaltic composition is much more advanced, which seems related to their high porosity and permeability. Mineralogically, they differ by much more abundant chloritization, and albitization not noted in basalts. The alteration of rhyodacites and tuffs of felsic composition seems less advanced than basaltic tuffs but more advanced than of the neighboring flood basalts, as best illustrated by the Kobryn profile (Supplementary Table 2). The abundance of felsic tuffs in the entire profile of the volcanic province indicates that felsic volcanism was active during much longer period than indicated by the known felsic lavas of the middle volcanogenic series (e.g. Kuzmenkova et al., 2011).

The detected mineral assemblage: from smectite to chlorite with zeolites, but without major albitization, epidote, actinolite, or amphibole puts the upper temperature limit of postmagmatic, pre-weathering alteration at ca. $220^{\circ} \mathrm{C}$ and lower at $50^{\circ} \mathrm{C}$, based on the calibration in the Icelandic active hydrothermal systems (Franzson et al., 2008: cf. Introduction) and many other smectite-to-chlorite transformation series reviewed by Robinson et al. (2002). The 
evidence of such maximum temperature conditions comes from most tuffs and the most altered flood basalts. Low $\delta^{18} \mathrm{O}$ of chlorite $(10.1 \%$ for Kob-23 sample) is consistent with a temperature of $190^{\circ} \mathrm{C}$ if a magmatic fluid with ca. 6\%o is assumed (Cole and Ripley, 1998). In this scenario, chlorite is considered as an indicator of a higher temperature overprint, which 891 altered older iron saponite, formed by the interaction of basalt with the heated meteoric waters. Locally, the temperatures of Ediacaran alteration may have been even higher, as albite, prehnite, and pumpellyite were reported (Emetz et al., 2006; Melnychuk, 2006), and epidote was identified in the olivine pseudomorphs in samples from west Belarus (Skveriki well: Kuzmenkova, 2009.). On the other hand, most flood basalts were altered by much cooler

896 fluids, as evidenced by the lack of chlorite and by the preservation of fresh organic material.

897 Our data confirm earlier observations that the extent of basalt alteration is controlled by the temperature and permeability. Figure 14 presents a synthetic model of the basalt alteration during the hydrothermal episode.

The second alteration episode, evidenced by K-Ar dating (Table 1 and Liivamägi et 901 al., 2018) and detected earlier by Ar-Ar of the whole rock samples (Elming et al., 2007), 902 involved the crystallization of aluminoceladonite and potassium feldspar (Liivamägi et al., 903 2018) and alteration of dioctahedral smectite into illite-smectite. K-Ar identifies two thermal events on the cratonic foreland of neighboring orogenic systems: in more northern locations (Belarus and Poland) related to the Caledonian orogeny, and in Volyn - to the Variscan. This late diagenetic alteration affected porous tuffs to a greater extent than flood 907 basalts, and within the flood basalts, it preferentially affected samples more intensely altered 908 by the first alteration episode, i.e. with higher secondary porosity. The temperature of this late 909 alteration was not higher than $85^{\circ} \mathrm{C}$, according to illite-smectite data from the overlying 910 sediments (Liivamägi et al., 2018) or even lower, according to the organic geochemistry data 
911 (Goryl et al., 2018). Apparently, in a high-Mg environment, aluminoceladonite can 912 crystallize at relatively low temperatures. Inline Supplementary Figure 7 demonstrates that potassium was imported into basalt

914 during the diagenetic alteration. In addition to potassium, enrichments in $\mathrm{Cs}, \mathrm{Rb}$, and $\mathrm{B}$ in 915 basalts can be also explained by this diagenetic event, based on their observed positive 916 correlations with $\% \mathrm{~K}_{2} \mathrm{O}$ and \% dioctahedral clay, and established knowledge of their 917 behavior (cf. Derkowski and McCarty, 2017 for Rb and Cs, and Środoń, 2010 for B). For 918 tuffs, such reasoning cannot be made, as their original $\mathrm{K}_{2} \mathrm{O}$ content is variable. Thus it 919 remains unclear whether $\mathrm{K}_{2} \mathrm{O}, \mathrm{Cs}, \mathrm{Rb}$, and $\mathrm{B}$ imported into flood basalts were derived locally 920 from felsic tuffs, or if these elements result from a more long-range transport.

921 Hydrothermal alteration of the Volyn-Brest basalt trap, in continental settings and 922 driven by heat of the cooling traps, can be considered as a good Earth analogue of the 923 Noachian basalt alteration on Mars. The Noachian alteration also produced Fe-rich smectites 924 and hematite (e.g. Ehlmann et al., 2011; Carter et al., 2103; Chemtob et al., 2015), which are 925 also interpreted as a result of subsurface basalt interaction with heated ground waters 926 (Ehlmann et al., 2011b), and are investigated with the techniques used in this study (XRD: 927 e.g. Blake et al., 2012, Downs et al. (2015); Mössbauer: e.g. Klingelhöfer et al., 2004; NIR: 928 e.g. Carter et al., 2013; Bishop et al., 2017). Particularly useful for Martian studies should be 929 (1) detail characterization of the Fe-smectite alteration products, which are also dominant on 930 Marsand in particular the role of redox in controlling the di/tri-smectite ratio; (2) detecting $931 \mathrm{Mg}$ enrichment during the alteration, considered indicative for the proposed alteration 932 mechanism, and inconsistent with weathering models (e.g. Le Deit et al., 2012); (3) limited 933 chemical changes despite radical changes in mineralogy, indicative for the proposed alteration 934 mechanism and analogous to the observations of Martian basaltic sediments (e.g., Bristow et 935 al., 2018): and (4) the location of elevated boron contents in illitized dioctahedral smectitic 
936 clays, which may explain Martian observations (e.g., Gasda et al., 2017). The analogy may 937 not be perfect, as the involvement of microorganisms in the alteration process of the 938 Ediacaran Volynian flood basalts is indicated by our data, which provide another piece of 939 evidence for the Ediacaran life on land.

940

$941 \quad \underline{\text { Acknowledgements }}$

942

Authors acknowledge financial support from the Polish National Science Centre MAESTRO grant 2013/10/A/ST10/00050, from the European Union (ERDF), and Région Nouvelle Aquitaine. We thank Anatoliy Makhnach for helpful discussions, Mariusz 946 Paszkowski for the pyroxene separation, Matgorzata Zielinska for the clay separations, 947 Zuzanna Ciesielska for collecting the XRD data, Michat Banaś for Ar isotope measurements, 948 and Dorota Bakowska for K measurements. Many thanks to the State Enterprise "Ukrainian 949 Geological Company" and Liubomyr Shymkiv personally, and the Republican Unitary 950 Enterprise "Research and Production Center for Geology", and Alla Laptsevich and Sergei 951 Mankevich personally for providing access to the core material and core descriptions. We 952 also thank Valerian Ciobotaru for providing four Moldavian samples. Exceptionally thorough 953 review by Elisabeth Rampe significantly improved quality of our presentation. Dennis D. 954 Eberl is thanked for final polishing our English.

955

$956 \underline{\text { References }}$

957

958 Alt, J. C., Honnorez, J., Laverne, C., Emmermann, R., 1986. Hydrothermal alteration of a 1 $959 \mathrm{~km}$ section through the upper oceanic crust, DSDP Hole 504B: mineralogy, chemistry, and 960 evolution of seawater-basalt interactions. Journal of Geophysical Research 91, 10309-10335. 
962 Alt, J.C., France-Lanord, Ch., Floyd, P. A., Castillo, P., Galy, A., 1992. Low-temperature 963 hydrothermal alteration of Jurassic ocean crust, Site 801. In: Proceedings of the Ocean

964 Drilling Program, Larson, R., Lancelot, Y. (Ed.), Scientific Results 129, 415-427.

965

966 Bakun-Czubarow, N., Białowolska, A., Fedoryshyn, Y., 2002. Neoproterozoic flood basalts 967 of Zabolottya and Babino Beds of the volcanogenic Volhynian Series and Polesie Series 968 dolerites in the western margin of the East European Craton. Acta Geologica Polonica 52, 969 $481-496$

970

971 Bau, M., 1991. Rare-earth element mobility during hydrothermal and metamorphic fluid-rock 972 interaction and the significance of the oxidation state of europium. Chemical Geology 93, 973 $219-230$.

974

975

Białowolska, A., Bakun-Czubarow, N., Fedoryshyn, Y., 2002. Neoproterozoic flood basalts 976 of the upper beds of the Volhynian Series (East European Craton). Geological Quarterly 46, $977 \quad 37-57$.

978

Bishop, J.L., Michalski, J.R., Carter, J., 2017. Remote detection of clay minerals. In: Infrared 980 and Raman Spectroscopies of Clay Minerals, Gates, W.P., Kloprogge, J.T., Madejova, J., 981 Bergaya F. (Eds.), Developments in Clay Science, 482-514.

982 Bishop, J. L., Fairén, A. G., Michalski, J. R., Gago-Duport, L., Baker, L. L., Velbel, M. A., ... 983 \& Rampe, E. B., 2018. Surface clay formation during short-term warmer and wetter 984 conditions on a largely cold ancient Mars. Nature Astronomy 2(3), 206.

985 
986 Blake, D.F. and 21 coauthors, 2012. Characterization and calibration of the CheMin 987 mineralogical instrument on Mars Science Laboratory. Space Science Reviews 170, 341-399. 988

Bobrovskiy, I., Hope, J.M., Krasnova, A., Ivantsov, A., Brocks, J.J., 2018. Molecular fossils 990 from organically preserved Ediacara biota reveal cyanobacterial origin for Beltanelliformis. 991 Nature Ecology \& Evolution, DOI: https://doi.org/10.1038/s41559-017-0438-6

992

Bowen, G. J., Revenaugh, J., 2003. Interpolating the isotopic composition of modern meteoric 994 precipitation. Water Resources Research 39(10), 1299.

995

996 Bristow, T. F., Rampe, E. B., Achilles, C. N., Blake, D. F., Chipera, S. J., Craig, P., ... \& 997 Grotzinger, J. P., 2018. Clay mineral diversity and abundance in sedimentary rocks of Gale 998 crater, Mars. Science Advances 4(6), eaar3330.

999 Cannon, K. M., Parman, S. W., \& Mustard, J. F., 2017. Primordial clays on Mars formed 1000 beneath a steam or supercritical atmosphere. Nature, 552(7683), 88.

1001 Carter, J., Poulet, F., Bibring, J.P., Mangold, N., Murchie, S., 2013. Hydrous minerals on 1002 Mars as seen by the CRISM and OMEGA imaging spectrometers: Updated global view. 1003 Journal of Geophysical Research Planets 118, 831-858.

1004

1005 Chemtob, S.M., Nickerson, N.Y., Morris, R.V., Agresti, D.G., Catalano, J.G., 2015. Synthesis 1006 and structural characterization of ferrous trioctahedral smectites: Implications for clay mineral 1007 genesis and detectability on Mars. Journal of Geophysical Research Planets 120, 1119-1140. 
1009 Chukanov, N.V., Pekov, I.V., Zadov, A.E., Chukanova, V.N., Möckel, S., 2003. 1010 Ferrosaponite $\mathrm{Ca} 0.3(\mathrm{Fe} 2+, \mathrm{Mg}, \mathrm{Fe} 3+) 3 \cdot(\mathrm{Si}, \mathrm{Al}) 4 \mathrm{O} 10(\mathrm{OH}) 2 \cdot 4 \mathrm{H} 2 \mathrm{O}$, the new trioctahedral 1011 smectite. Zapiski Vserossiyskogo Mineralogicheskogo Obshchestva 132, 68-74 (in Russian).

1012

1013 Cole, D.R., Ripley, E.M., 1998. Oxygen isotope fractionation between chlorite and water 1014 from $170-350^{\circ} \mathrm{C}$ : A preliminary assessment based on partial exchange and fluid/rock 1015 experiments. Geochimica et Cosmochimica Acta 63, 449-457.

1016

1017 Compston, W., Sambridge, M.S., Reinfrank, R.F., Moczydłowska, M., Vidal, G., Claesson, 1018 S., 1995. Numerical ages of volcanic rocks and the earliest faunal zone within the Late 1019 Precambrian of east Poland. Journal of the Geological Society 152, 599-611.

1020

1021 Craw, D., Blattner, P., Landis, C.A., 1995. Stable isotopic signatures of authigenic minerals in 1022 a Holocene ophiolitic debris flow, Southland, New Zealand. Clay Minerals 30, 165-172.

1023

1024 Dainyak, L.G., Drits, V.A., Kudryavtsev, D.I., Simanovych, I.M., Slonimskaya, M.B., 1981. 1025 New variety of trioctahedral smectite from effusive basalts of Tunguskaya Sineclise. Litologia 1026 i Poleznye Iskopayemye 6, 123-129 (in Russian).

1027

1028 Derevska, K., Shumlyanskyy, V., Galetskyy, L., Zagnitko, V., Pryhod'ko, V., Bezugla, M., 1029 Shumlyanskyy, L., 2006. Geological genetic model of ore-forming sysytem andprospecting 1030 criteria of native copper in the Volynian flood basalts. In: Copper of the Volynian Region, 1031 Shumlyanskyy L.V. (Ed.), Logos, Kiyv, 46 - 55 (in Ukrainian). 
1033 Derkowski, A., McCarty, D.K., 2017. Cesium, a water-incompatible, siloxane-complexed

1034 cation in Earth's upper crust. Geology 45, 899-902.

1035

1036 Derkowski, A., Środoń, J., McCarty, D.K., 2015. Cation exchange capacity and water

1037 content of opal in sedimentary basins: example from the Monterey Formation, California.

1038 American Mineralogist 100, 1244-1256.

1039 Downs, R.T. and MSL Science Team, 2015. Determining mineralogy on Mars with the 1040 CheMin X-ray diffractometer. Elements 11, 45-50.

1041 Eberl, D.D., Środoń, J., Lee, M., Nadeau, P.H., Northrop, H.R., 1987. Sericite from the 1042 Silverton caldera, Colorado: Correlation among structure, composition, origin, and particle 1043 thickness. American Mineralogist 72, 914-934.

1044 Ehlmann, B.L., Mustard, J.F., Clark, R.N., Swayze, G.A., Murchie, S.L., 2011a. Evidence for 1045 low-grade metamorphism, hydrothermal alteration, and diagenesis on Mars from 1046 phyllosilicate mineral assemblages. Clays and Clay Minerals 59, 359-377.

1047

1048 Ehlmann, B.L., Mustard, J.F., Murchie, S.L., Bibring, J-P., Meunier, A., Fraeman, A.A., 1049 Langevin, Y., 2011b. Subsurface water and clay mineral formation during the early history of 1050 Mars. Nature 479, 53-60.

Eiler, J.M., 2001. Oxygen isotope variations of basaltic lavas and upper mantle rocks. Reviews in Mineralogy and Geochemistry 43, 319-364.

1054 
1055 Elie, M., Faure, P., Michels, R., Landais, P, Griffault L., 2000. Natural and laboratory 1056 oxidation of low-organic-carbon-content sediments: comparison of chemical changes in 1057 hydrocarbons. Energy \& Fuels 14, 854-861.

1058

1059 Elie, M., Faure, P., Michels, R., Landais, P, Griffault L., Mansuy, L., Martinez, L., 2004.

1060 Effects of water-cement solutions on the composition of organic compounds leached from 1061 oxidized Callovo-Oxfordian argillaceous sediment. Applied Clay Science 26, 309-329.

1062

1063 Elming, S.Å., Kravchenko, S.N., Layer, P., Rusakov, O.M., Glevasskaya, A.M., Mikhailova, 1064 N.P., Bachtadse, V., 2007. Palaeomagnetism and ${ }^{4}{ }^{0} \mathrm{Ar} /{ }^{3}{ }^{9} \mathrm{Ar}$ age determinations of the 1065 Ediacaran traps from the southwestern margin of the East European Craton, Ukraine: 1066 relevance to the Rodinia break-up. Journal of the Geological Society 164, 969-982.

1067

1068 Emetz, A., Piestrzyński, A., Zagnitko, V., 2004. Geological framework of the Volhyn copper 1069 fields with a review of the Volhyn flood basalt province (western margin of the East1070 European Craton). Annales Societatis Geologorum Poloniae 74, 257-265.

1071

1072 Emetz, A., Piestrzyński, A., Zagnitko, V., Pryhod'ko L., Gaweł A., 2006. Geology, 1073 mineralogy and origin of Zhyrychi native copper deposit (North-Western Ukraine). Annales 1074 Societatis Geologorum Poloniae 76, 297-314.

1075

1076 Farmer, G.L., 2003. Continental Basaltic Rocks. In: Treatise on Geochemistry, Elsevier, 1077 Amsterdam, vol. 3, 85-121.

1078 
1079 Faust, G.T., 1955. Thermal analysis and X-ray studies of griffithite. Journal of the 1080 Washington Academy of Sciences 45, 66-70.

1081

1082 Franzson, H., Zierenberg, R., Schiffman, P., 2008. Chemical transport in geothermal systems 1083 in Iceland: Evidence from hydrothermal alteration. Journal of Volcanology and Geothermal 1084 Research 173, 217-229.

1085 Gasda, P. J., Haldeman, E. B., Wiens, R. C., Rapin, W., Bristow, T. F., Bridges, J. C., ... \& 1086 Lanza, N. L., 2017. In situ detection of boron by ChemCam on Mars. Geophysical Research 1087 Letters 44(17), 8739-8748.

1088 Goryl, M., Marynowski, L., 2016. Pattern of $n$-alkanes distribution characteristic for 1089 terrestrial organic matter from the Ediacaran sedimentary rocks of the East European 1090 Platform. Mineralogia - Special Papers 45, 57.

1091

1092 Goryl, M., Marynowski, L., Brocks, J.J., Bobrovskiy, I., Derkowski, A., 2018. Exceptional 1093 preservation of hopanoid and steroid biomarkers in Ediacaran sedimentary rocks of the East 1094 European Craton. Precambrian Research 316, 38-47.

1095

1096 Harmon, R. S., Hoefs, J., 1995. Oxygen isotope heterogeneity of the mantle deduced from 1097 global ${ }^{18} \mathrm{O}$ systematics of basalts from different geotectonic settings. Contributions to 1098 Mineralogy and Petrology 120, 95-114.

1099

1100 Jambor, J.N., Roberts, A.C., 2004. New mineral names. American Mineralogist 89, 467-471. 
1102 Juskowiak, O., Ryka, W., 1967. Volcanic and accompanying sedimentary rocks from

1103 boreholes Kruszyniany and Mielnik. Biuletyn Instytutu Geologicznego 197, 69-103 (in 1104 Polish).

1105

1106 Juskowiakowa, M., 1971. Basalts of eastern Poland. Biuletyn Instytutu Geologicznego 245, 1107 175-253 (in Polish).

1108

1109 Juskowiakowa, M., 1974. Upper Precambrian sediments. Prace Instytutu Geologicznego 74, 1110 20-39 (in Polish).

1111

1112 Kamieński, M., 1929. Volyn basalts. Kosmos 54, 675-701 (in Polish).

1113

1114 Klingelhöfer, G., Morris, R.V., Bernhardt, B., Schröder, C., Rodionov, D.S., de

1115 -Souza, P.A., Yen, A., Gellert, R., Evlanov, E.N., Zubkov, B., and others, 2004.

1116 Jarosite and hematite at Meridiani Planum from Opportunities Mössbauer

1117 spectrometer. Science 306, 1740-1745.

1118

1119 Kohn, M.J., Valley, J.W., 1998. Oxygen isotope geochemistry of the amphiboles:

1120 Isotope effects of cation substitutions in minerals. Geochimica et Cosmochimica Acta

$1121 \quad 62,1947-1958$.

1122

1123 Komadel, P., Madejová, J., Laird, D.A., Xia, Y., Stucki, J.W., 2000. Reduction of Fe(III) in 1124 griffithite. Clay Minerals 35, 625-634.

1125

1126 Kremer, B., Kaźmierczak, J., Środoń, J., 2018. Cyanobacterial-algal crusts from Late 
1127 Ediacaran paleosols of the East European Craton. Precambrian Research 305, 236-246.

1129 Kuzmenkova, O.F., 2005. Zeolites of the Vendian basalts of Belarus. In: Proceedings of the

1130 National Academy of Sciences of Belarus, Chemical Series 5, 158-160 (in Russian).

1132 Kuzmenkova, O.F., 2007. Petrography of magmatic rocks of the trap formation of Belarus.

1133 Lithosphere 27, 81-95. (in Russian).

1134

1135 Kuzmenkova, O.F., 2009. Geochemistry of the trappean formation of the Vendian of Belarus:

$1136 \mathrm{PhD}$ thesis, Republican Unitary Enterprise "Belarussian Research and Exploration Institute",

1137 Minsk, 22 pp. (in Russian).

1138

1139 Kuzmenkova, O.F., 2011. Material composition of the Khotislavsky cooper occurrence. In:

1140 Actual Problems of Modern Geology, Geochemistry and Geography, Materials of the

1141 International Scientific-Practical Conference, Brest, Part 1. Geology and Geochemistry, 118-

1142120 (in Russian).

1143

1144 Kuzmenkova, O.F., Veretennikov, N.V., Nosova, A.A., Kotlyarov, V.A., 2006a. Copper

1145 mineralization in the Vendian volcanogenic strata of Belarus. In: Copper of the Volynian

1146 Region, Shumlyanskyy L.V. (Ed.), Logos, Kiyv, 171-178 (in Russian).

1148 Kuzmenkova, O.F. Veretennikov, N.V., Samodurov, V.P., 2006b. Genesis of the analcime1149 chlorophaeite-containing basalts of the Neoproterozoic (Vendian) trap formation of Belarus.

1150 In: Volcanism and Geodynamics. Materials of the III All-Russian Symposium on

1151 Volcanology and Paleovolcanology, Ulan-Ude, Vol. 3, 641-645 (in Russian). 
1153 Kuzmenkova, O.F., Nosova, A.A., Veretennikov, N.V., 2008. Mineralogy and petrogenesis of

1154 Vendian basalts and dolerites of Belarus. Lithosphere 28, 76-95 (in Russian).

1156 Kuzmenkova, O.F., Nosova, A. A., Shumlyansky, L.V., 2010. Comparison of Neoproterozoic

1157 Volyn-Brest magmatic province with large world continental plate basalt provinces, the 1158 nature of low- and high-Ti basite magmatism. Lithosphere 33, 3-16 (in Russian).

1159

1160 Kuzmenkova, O.F., Shumlyansky, L.V., Nosova, A.A., Voskoboynikova, T.V., Grakovich, 1161 I.J., 2011. Petrology and correlation of trap formations of the Vendian in the adjacent areas of 1162 Belarus and Ukraine. Lithosphere 35, 3-23.

1163

1164 Kvasnytsya, I., Kosovskyy, Y., Bondarenko, I., 2006. Native iron from Volyn Vendian 1165 volcanogenic rocks. In: Copper of the Volynian Region, Shumlyanskyy L.V. (Ed.), Logos, 1166 Kiyv, 123-131 (in Ukrainian).

1167

1168 Lazarenko, E.K., 1956. About seladonite from Volyn basalts. Mineralny Sbornik Lvovskoho 1169 Geologicheskoho Obshestva 10, 352-362 (in Ukrainian).

1170

1171 Le Deit, L., Flahaut, J., Quantin, C., Hauber, E., Mège, D., Bourgeois, O., Gurgurewicz, J.,

1172 Massé, M., Jaumann, R., 2012. Extensive surface pedogenic alteration of the Martian

1173 Noachian crust suggested by plateau phyllosilicates around Valles Marineris, Journal of

1174 Geophysical Research 117, E00J05, doi:10.1029/2011JE003983.

1175 
1176 Levykh, N.N., 1999. Weathering crusts of the western part of the East European platform.

1177 Institute of Geological Sciences, Belarussian Academy of Sciences, Minsk, 204 pp. (in

1178 Russian).

1179

1180

1181

1182

1183

1184

1185

1186

1187

1188

1189

1190

1191

1192

1193

1194

1195

1196

1197

1198 Mazur, S., Porębski, S.J., Kędzior, A., Paszkowski, M., Podhalańska, T., Poprawa, P., 2018a.

1199 Refined timing and kinematics for Baltica-Avalonia convergence based on the sedimentary

1200

Liivamägi, S., Środoń, J., Bojanowski, M., Gerdes, A., Stanek, J. J., Williams, L., Szczerba, M., 2018. Paleosols on the Ediacaran basalts of the East European Craton: a unique record of paleoweathering with minimum diagenetic overprint. Precambrian Research 316, 66-82.

Madejová, J., Gates, W.P., Petit, S., 2017. IR Spectra of Clay Minerals. In: Infrared and Raman Spectroscopies of Clay Minerals, Gates, W.P., Kloprogge, J.T., Madejova, J., Bergaya, F. (Eds.), Developments in Clay Science, Elsevier, 105-149.

Makhnach, A.A., Veretennikov, N.V., 1970.Volcanogenic formation of the Upper Proterozoic (Vendian) of Belarus. Science and Technology, Minsk, 236 pp. (in Russian).

Małkowski, S., 1929. On discovery of the native copper deposit in Volyn. Biuletyn Państwowego Instytutu Geologicznego 24, 16-17 (in Polish).

Marynowski, L., Wyszomirski, P., 2008. Organic geochemical evidences of early diagenetic oxidation of the terrestrial organic matter during the Triassic arid and semi-arid climatic conditions. Applied Geochemistry 23, 2612-2618.

\footnotetext{
record of a foreland basin. Terra Nova 30, 1-8.
} 
1201 Mazur, S., Krzywiec, P., Malinowski, M., Lewandowski, M., Aleksandrowski, P., 1202 Mikołajczak, M., 2018b. On the nature of the Teisseyre-Tornquist Zone. Geology, 1203 Geophysics and Environment 44, 17-30.

1204

1205 Melnychuk, V.G., 2006. Hydrothermal mineralogical zonality and metamorphism in copper1206 bearing Vendian flood basalts of the Volyno-Podolian plate. In: Copper of the Volynian 1207 Region, Shumlyanskyy L.V. (Ed.), Logos, Kiyv, 131 - 142 (in Ukrainian).

1208

1209 Mysiak, I.M., Skakun, L.Z., Serkiz, R.Y., 2016. Unusual association of native metals in the 1210 platobasalts of Volyn and conditions of their formation. Mineralogical Journal (Ukraine) 38, 1211 14-22 (in Ukrainian).

1212

1213 Nawrocki, J., Poprawa, P., 2006. Development of Trans-European Suture Zone in Poland: 1214 from Ediacaran rifting to Early Palaeozoic accretion. Geological Quarterly 50, 59-76.

1215

1216 Nehring-Lefeld, M., Modlinski, Z., Swadowska, E., 1997. Thermal evolution of the 1217 Ordovician in the western margin of the East-European Platform: CAI and $\mathrm{R}_{0}$ data. 1218 Geological Quarterly 41, 129-138.

1220 Nosova, A.A., Kuzmenkova, O.F., Veretennikov, N.V., Petrova, L.G., Levsky, L.K., 2008.

1221 Neoproterozoic Volhynia-Brest magmatic province in the western East European Craton:

1222 withing-plate magmatism in ancient suture zone. Petrology 16, 105-135 (in Russian). 1223 
1224 Pacześna, J., 2010. The evolution of late Ediacaran riverine-estuarine system in the Lublin-

1225 Podlasie slope of the East European Craton, southeasten Poland. Polish Geological Institute 1226 Special Papers 27, 1-96.

1227

1228 Peacock, M.A., Fuller, R.E., 1928. Chlorophaeite, sideromelane and palagonite from the 1229 Columbia River Plateau. American Mineralogist 13, 369-382.

1230

1231 Pehr, K., Love, G.D., Kuznetsov, A., Podkovyrov, V., Junium, C.K., Shumlyanskyy, L., 1232 Sokur, T., Bekker, A., 2018. Ediacara biota flourished in oligotrophic and bacterially 1233 dominated marine environments across Baltica. Nature Communications 9, 1807. DOI: 1234 https://doi.org/10.1038/s41467-018-04195-8

1235 Poprawa, P., Šliaupa, S., Stephenson, R., Lazauskiene, J., 1999. Late Vendian-Early 1236 Palæozoic tectonic evolution of the Baltic Basin: regional tectonic implications from 1237 subsidence analysis. Tectonophysics 314, 219-239.

1238

1239 Rajchel, J., 2012. Antique cobblestone pavement in Krakow. Brukbiznes 3, 18-23 (in Polish). 1240

1241 Robinson, D., Schmidt, S.Th., Santana De Zamora, A., 2002. Reaction pathways and reaction 1242 progress for the smectite-to-chlorite transformation: evidence from hydrothermally altered 1243 metabasites. Journal of Metamorphic Geology 20, 167-174.

1244

1245 Rollinson, H.R., 1994. Using Geochemical Data: Evaluation, Presentation, Interpretation. 1246 Longman Scientific \& Technical, 352 pp. 
1247 Ross, C.S., 1960. Review of the relationships in the montmorillonite group of clay minerals.

1248 Clays and Clay Minerals. Proceedings of the Seventh National Conference on Clays and Clay 1249 Minerals, 225-229.

1250 Rouxel, O., Dobbek, N., Ludden, J., Fouquet, Y., 2003. Iron isotope fractionation during 1251 oceanic crust alteration. Chemical Geology 202, 155-182.

1252

1253 Rybicki, M., Marynowski, L., Misz-Kennan, M., Simoneit, B.R.T., 2016. Molecular tracers 1254 preserved in Lower Jurassic "Blanowice brown coals" from southern Poland at the onset of 1255 coalification: Organic geochemical and petrological characteristics. Organic Geochemistry $1256102,77-92$.

1257

1258 Sarkar, P.K., Upasani, D.V., Wani, V., 2016. Alteration of volcanic glass to well-crystallized 1259 ferrosaponite in the vesicles of the Deccan trap basalts at Bhuleshwar Ghat section, Pune 1260 district, Maharashtra. Journal of the Geological Society of India 88, 22-28.

1261 Savin, S.M., Lee, M., 1988. Isotopic studies of phyllosilicates. Reviews in Mineralogy 19, $1262 \quad 189-223$.

1263 Schmidt, S.Th., 1993. Regional and local patterns of low-grade metamorphism in the North 1264 Shore Volcanic Group, Minnesota, USA. Journal of Metamorphic Geology 11, 401-414. 
1265 Schmidt, S.Th., Robinson, D., 1997. Metamorphic grade and porosity and permeability 1266 controls on mafic phyllosilicate distributions in a regional zeolite to greenschist facies 1267 transition of the North Shore Volcanic Group, Minnesota. GSA Bulletin 109, 683-697.

1268 Shau, Y-H., Peacor, D.R., 1992. Phyllosilicates in hydrothermally altered basalts from DSDP 1269 Hole 504B, Leg 83 - a TEM and AEM study. Contributions to Mineralogy and Petrology $1270 \quad 112,119-133$.

1271

1272 Sheppard, S.M.F., Gilg, H.A., 1996. Stable isotope geochemistry of clay minerals. Clay 1273 Minerals 31, 1-24.

1274

1275 Shumlyanskyy, L.V. (Ed.), 2006. Copper of the Volynian Region. Logos, Kiyv (in Russian 1276 and Ukrainian).

1278 Shumlyanskyy, L.V., Tsymbal, S.M., 2006. On the character of secondary alteration of 1279 volcanogenic rocks of the Volynian flood basalt province. In: Shumlyanskyy L.V.V. (Ed.), 1280 Copper of the Volynian Region. Logos, Kiyv, 56 - 66 (in Ukrainian).

1281

1282 Shumlyanskyy, L.V., Nosova, A., Billstrom K., Soderlund U., Andreasson, P.G., 1283 Kuzmenkova, O., 2016. The U-Pb zircon and baddeleyite ages of the Neoproterozoic Volyn 1284 Large Igneous Province: implication for the age of the magmatism and the nature of a crustal 1285 contaminant. GFF 138, 17-30.

1286

1287 Simanovich, I.M., Drits, V.A., Dainyak, L.G., 1986. Smectites and isotropic phases in basalts 1288 of northern Timan. Lithology and Mineral Resources 1, 86 - 103 (in Russian). 
1290 Simanovich, I.M., Yapaskurt, O.V., Gorbachev, V.I., 2010. Trap magmatism and 1291 mobilization of hydrocarbon fluids (Western Siberia). Moscow University Geology Bulletin $129265,153-160$.

1293

1294 Skakun L., Tkachuk A., Melnychuk V. 2006. Formation of zeolite mineralization in the 1295 hydrothermal rocks of of the flood basalts of Volynian series. In: Copper of the Volynian 1296 Region, Shumlyanskyy L.V.V. (Ed.), Logos, Kiyv, 71 - 81 (in Ukrainian).

1298 Środoń, J., 2010. Evolution of boron and nitrogen content during illitization of bentonites.

1299 Clays and Clay Minerals 58, 743-756.

1300

1301 Środoń, J., Clauer, N., Eberl, D.D., 2002. Interpretation of K-Ar dates of illitic clays from 1302 sedimentary rocks aided by modelling. American Mineralogist 87, 1528-1535.

1303

1304 Środoń J., Zeelmaekers E., Derkowski A., 2009. The charge of component layers of illite1305 smectite in bentonites and the nature of end-member illite. Clays \& Clay Minerals 57, 649$1306 \quad 671$.

1307

1308 Stone, C., Fan, P., 1978. Hydrothermal alteration of basalts from Hawaii Geothermal Project

1309 Well-A, Kilauea, Hawaii. Geology 6, 401-404.

1311 Stroncik, N.A., Schmincke, H-U., 2002. Palagonite - a review. International Journal of Earth

1312 Sciences (Geologische Rundschau) 91, 680-697. 
1314 Sun, S.-s., McDonough, W.F., 1989. Chemical and isotopic systematics of oceanic basalts:

1315 implications for mantle composition and processes. Geological Society Special Publication $1316 \quad 42,313-345$.

1318 Teutsch, N., Schmid, M., Müller, B., Halliday, A.N., Bürgmann, H., Wehrli, B., 2009. Large 1319 iron isotope fractionation at the oxic-anoxic boundary in Lake Nyos. Earth and Planetary 1320 Science Letters 285, 52-60.

1323 \& Bish, D. L., 2014. Ferrian saponite from the Santa Monica Mountains (California, USA, 1324 Earth): Characterization as an analog for clay minerals on Mars with application to 1325 Yellowknife Bay in Gale Crater. American Mineralogist 99, 2234-2250.

1327 Ushakova, Z.G., 1962. Lower Paleozoic trap formation in western part of the Russian 1328 platform. WSEGEI Works (Труды ВСЕГЕИ) 30, 108 pp. (in Russian).

1330 Vaniman, D. T., Bish, D. L., Ming, D. W., Bristow, T. F., Morris, R. V., Blake, D. F., ... \& 1331 Rice, M., 2014. Mineralogy of a mudstone at Yellowknife Bay, Gale crater, 1332 Mars. Science, 343(6169), 1243480.

1334 Weill, D.F., Drake M.J., 1973. Europium anomaly in plagioclase feldspar: experimental 1335 results and semiquantitative model. Science 180, 1059-1060. 
1337 Wu, L., Beard, B.L., Roden, E.E., Kennedy, C.B, Johnson, C.M., 2010. Stable Fe isotope

1338 fractionations produced by aqueous $\mathrm{Fe}(\mathrm{II})$-hematite surface interactions. Geochimica et 1339 Cosmochimica Acta 74, 4249-4265.

\section{Tables}

1343 Table 1. Decomposition of Mössbauer spectra of rocks and selected clay fractions, $\% \mathrm{Fe}^{2+}$ in

1344 total Fe calculated from the decomposition data for bulk rock and clay fraction, oxygen and 1345 iron isotope data, along with \% primary minerals from Supplementary Table 1.

1347 Table 2. Chemical composition (wt\% SEM/EDS microchemical analyses) of isotropic 1348 chlorophaeite and replacing birefringent smectititic clays in different sites of the basaltic rock 1349 affected by incipient alteration (sample 4522-1). Ferrous state has been assigned to iron in all 1350 analyses.

1352 Table 3. K-Ar data for selected clay fractions containing aluminoceladonite and/or illite1353 smectite (cf. Supplementary Table 3).

1356 formulae derived from published chemical data of similar materials: griffithite from Ross 1357 (1960) and Komadel et al. (2000), oxysmectites from Dainyak et al. (1981), and ferrosaponite 1358 from Jambor et al. (2004). Formula of chlorite (Kob-23) added to show tendency in chemical composition of clays. 
1361 Table 5. Characteristics of end-member di- and trioctahedral smectite from Volynian basalts

1362 extrapolated using number of atoms in the octahedral sheet given in Table 4.

1364 Supplementary Table 1. Quantitative XRD mineral composition data for basalts, green clays 1365 from veins and cavities in basalt, and rhyodacites, plus XRD estimates of chlorophaeite 1366 composition. Basalts arranged by alteration steps I-V, based on sum of primary minerals. If 1367 data available, basalts are assigned to lower or upper volcanic series.

1369 Supplementary Table 2. Quantitative XRD mineral composition data for tuffs and for basalt1370 tuff alternation in section Kobryn. Tuffs arranged from felsic to basic, based on the content of 1371 quartz. If data available, samples are assigned to lower or upper volcanic series.

1372

1373 Supplementary Table 3. Mineral composition of $<0.2 \mu \mathrm{m}$ fractions, separated from basalts, 1374 green clays in veins and cavities, and tuffs. The peak position data, used in the evaluation of 1375 percent smectite layers $(\% \mathrm{~S})$ in illite-smectite are given along with calculated $\% \mathrm{~S}$ and the 1376 average $\% \mathrm{~S}$ value. tr: trace, i-s: illite-smectite, ch-s: chlorite-smectite, $\delta 2$ : angular distance 1377 between i-s reflections in $42-49^{\circ} 2 \Theta$ range.

1379 Supplementary Table 4. Chemical composition of basalts, chlorophaeite, green clays from 1380 veins and cavities in basalt, rhyodacites, tuffs, and clay fractions. Major elements and loss on 1381 ignition (LOI) given in \%, trace elements in ppm. Below average values for different 1382 lithologies and compositions of clay fractions along with their bulk rocks are listed. 
1386 Figure 1. Map of the Volyn-Brest volcanic province with sampling sites indicated (modified

1387 from Kuzmenkova et al., 2010, TTZ after Mazur et al., 2018b).

1389 Figure 2. Random powder XRD patterns of the bulk rock, with ZnO internal standard, 1390 illustrating the compositional variability of Volyn basalts, reflecting the degree of 1391 hydrothermal alteration.

1392

1393 Figure 3. Random powder XRD patterns of the chlorophaeite accumulations, registered in 1394 glass tubes because of the scarcity of the available material, and documenting coexistence of 1395 di and trioctahedral smectite (02 peaks at 4.48 and $4.58 \AA$, respectively).

Figure 4. ${ }^{57} \mathrm{Fe}$ room temperature Mössbauer spectra of bulk rock basalts, chlorophaeite 1399 (Mokrany-3A), chloritic clay in basalt (Kob-23), and tuffs (B), illustrating the variability of 1400 compositions encountered, and presented along with calculated spectra of iron-bearing 1401 fractions used in the fitting procedure.

1403 Figure 5. FTIR transmission $\mathrm{KBr}$ spectra $(<0.2 \mu \mathrm{m}$ fraction) of basaltic clays: Mokrany-3B 1404 and 4504-1A, with end-member components used as references: chlorite (Kob-23), 1405 trioctahedral smectite (4600-1), and dioctahedral smectite from paleosol (4517-1); Qz: quartz 1406 (distinctive bands).

1408 Figure 6. FTIR transmission $\mathrm{KBr}$ spectra of chlorophaeite accumulations (a) and surrounding 1409 basalts (b); Qz: quartz (distinctive bands), Pl: feldspars (distinctive bands). 
1411 Figure 7. Partial $\mathrm{m} / \mathrm{z} 71$ mass chromatogram for TMS derivatized basalt extract showing the 1412 odd-over-even long chain $n$-alkanes predominance (A) and partial $\mathrm{m} / z \quad 117$ mass

1413 chromatograms showing comparison of $n$-alkanoic acids for unaltered basalt (4600-3B) and

1414 cavity clay (4600-3A). Note high-molecular-weight $n$-alkanoic acids (26 to 32) in the basalt

1415 sample (B). Numbers denote carbon atoms in the molecule.

1417 Figure 8. Photomicrographs (optical microscopy) and SEM images (BSE mode) of isotropic 1418 chlorophaeite (A-D) and its smectitic alteration products (E-H). (A) Intersertal chlorophaeite 1419 through the body of the basaltic rocks (sample 4522-1). (B) Chlorophaeite with collomorph 1420 texture coating the wall of circular cavities (sample 4522-1). (C) chlorophaeite pseudomorphs 1421 after orthopyroxene (sample 4603-1). (D) Chlorophaeite as veinlet and filling product of 1422 diktytaxitic voids in the wall-rock (sample 4522-1). (E) Incipient alteration of chlorophaeite at 1423 the contact of a plagioclase microlite (sample 4522-1). (F) Details of the clay-rich 1424 microspherules related to incipient alteration of chlorophaeite (sample 4522-1). (G) Strong 1425 replacement of chlorophaeite, partial replacement of chlorite and local dissolution of quartz 1426 filling a vesicle in a moderately altered basalt (sample 4519-0). (H) Morphological aspects of 1427 the smectitic clays as a function of alteration sites (sample 4519-0). Microspherules 1428 predominate in both altered chlorophaeite and chlorite while ribbon like morphology is 1429 observed when alteration is developed at the contact between quartz and chlorophaeite. Am: 1430 fresh chlorophaeite; Ze: zeolite; OPXps: chlorophaeite pseudomorph after orthopyroxene;

1431 CPX: clinopyroxene; Pl: plagioclase; Ma: magnetite; Amv: chlorophaeite veinlet; Sm 1432 smectitic clays; IRL: iron-rich layer; AH: alteration halo; Ch: iron rich chlorite; Qz: quartz.

1434 Figure 9. 
1435 Relationship between \% clay from $\mathrm{XRD}$ and \% $\mathrm{MgO}$ (red triangles) and \% LOI (loss on

1436 ignition) in basalts of variable degree of alteration. The LOI trend (blue diamonds)

1437 extrapolates to a value intermediate between rocks dominated by chlorite and smectite (pink

1438 squares).

1439

1440

1441 Figure 10. Primitive mantle normalized REE spectra of basalts with variable degree of

1442 alteration, chlorophaeite, vein clay (Fe-saponite), and rhyodacites.

1443

1444 Figure 11. Relationship between $\%$ primary minerals from XRD and $\delta^{18} \mathrm{O}_{\mathrm{VsMOw}}$ in basalts of

1445 variable degree of alteration, chlorophaeite accumulation, clay veins, and basaltic tuffs.

1446

1447 Figure 12. The oxygen isotope compositional ranges of smectites from paleosols, basalt, and

1448 green clay veins in basalt from this study plotted onto the relationship of equilibrium oxygen

1449 isotope fractionation between smectite and water as a function of temperature based the

1450 equation of Sheppard and Gilg (1996).

1451

1452 Figure 13. Relationship between \% primary minerals from XRD and percent divalent iron in

1453 total iron of basalts with variable degree of alteration, of their clay fractions, and of the

1454 chlorophaeite sample Mokrany-3A.

1455

1456 Figure 14. A synthetic model of basalt alteration during the hydrothermal episode, presenting

1457 the most important changes in mineral and chemical composition (details in the text). Pl -

1458 plagioclase, Py - pyroxene, M - magnetite+pseudobrookite+ilmenite, Z - zeolites, Ch - 
1459 chlorite, A - anatase, H - hematite, Ksp - K-feldspar, Q -quartz, Tri-S - Fe-saponite, Di-S - Fe-

1460 montmorillonite.

1463 Inline Supplementary Figure 1. Random powder XRD patterns of the bulk rock, with $\mathrm{ZnO}$ 1464 internal standard, illustrating the compositional variability of Volyn tuffs, from felsic (top) to 1465 basic (bottom), with rhyodacite Skv-0C as reference.

Inline Supplementary Figure 2. Oriented glycolated XRD patterns of $<0.2 \mu$ m clay fractions

1468 (with $\mathrm{MoS}_{2}$ as internal standard), representative for the variability encountered in basalts and 1469 green clays from veins and cavities in basalt.

1471 Inline Supplementary Figure 3. Random powder XRD patterns of $<0.2 \mu \mathrm{m}$ basalt clay 1472 fractions and $<2 \mu \mathrm{m}$ fraction of griffithite, documenting coexistence of di- and trioctahedral 1473 smectite. The reference griffithite sample from Griffith Park, California, was provided by Dr. 1474 Jana Madejova.

Inline Supplementary Figure 4. Oriented glycolated XRD patterns of $<0.2 \mu \mathrm{m}$ clay fractions,

1477 representative for the variability encountered in tuffs.

1479 Inline Supplementary Figure 5. ${ }^{57} \mathrm{Fe}$ room temperature Mössbauer spectra of minerals, used 1480 for decomposing spectra of bulk rocks (results of decomposition in Table 1).

1481 Inline Supplementary Figure 6. Relationship between \% plagioclase from $\mathrm{XRD}$ and \% $\mathrm{CaO}$ in 1482 basalts of variable degree of alteration. Three samples off the general trend (blue diamonds) 1483 contain calcite veinlets. 
1486 Inline Supplementary Figure 7. Relationship between \% dioctahedral clays from XRD and

1487 ppm boron in basalts of variable degree of alteration.

1488

1489 Inline Supplementary Figure 8. Relationship between $\% \mathrm{~K}_{2} \mathrm{O}$ calculated from XRD contents

1490 of $\mathrm{K}$-feldspar (assuming $12 \% \mathrm{~K}_{2} \mathrm{O}$ ) and dioctahedral clay $\left(6 \% \mathrm{~K}_{2} \mathrm{O}\right)$ and measured $\% \mathrm{~K}_{2} \mathrm{O}$ in 1491 basalts of variable degree of alteration.

1492

1493 Inline Supplementary Figure 9. Relationship between \% $\mathrm{P}_{2} \mathrm{O}_{5}$ and ppm LREE in bulk rocks.

1494

1495 Inline Supplementary Figure 10. Quantitative evolution of secondary minerals in the course of 1496 basalt hydrothermal alteration traced by percent of primary minerals.

1497

1498 Inline Supplementary Figure 11. Differentiation of tuffs into felsic (close to rhyodacite) and 1499 basaltic, based on quartz and K-feldspar XRD contents.

1500

1501 Inline Supplementary Figure 12. Chemical variability of tuffs (felsic vs. basaltic) traced using 1502 the most immobile trace elements.

1503

1504 Inline Supplementary Figure 13. Chemical differences between basalts and tuffs illustrated 1505 for a single profile (Kobryn) using the most immobile trace elements. 


\begin{tabular}{|c|c|c|c|c|c|c|c|c|c|c|c|c|c|c|c|c|}
\hline \multirow[t]{2}{*}{ Sample } & \multirow{2}{*}{$\begin{array}{c}\text { Hematite } \\
3+\end{array}$} & \multirow{2}{*}{$\begin{array}{c}\text { Magnetite } \\
3+\& 2+\end{array}$} & \multirow{2}{*}{$\begin{array}{c}\text { III-sm } \\
3+\end{array}$} & \multirow{2}{*}{$\begin{array}{c}\text { Saponite } \\
3+\end{array}$} & \multirow{2}{*}{$\begin{array}{c}\text { Saponite } \\
2+\end{array}$} & \multirow{2}{*}{$\begin{array}{c}\text { Chlorite } \\
2+\end{array}$} & \multirow{2}{*}{$\begin{array}{c}\text { Pyroxene } \\
2+\end{array}$} & \multirow{2}{*}{$\begin{array}{l}\% \mathrm{Fe}^{2+} \text { in } \\
\text { bulk rock } \mathrm{Fe}\end{array}$} & \multirow{2}{*}{$\begin{array}{l}\% \mathrm{Fe}^{2+} \text { in } \\
\text { clay } \mathrm{Fe}\end{array}$} & \multicolumn{2}{|c|}{$\delta^{18} \mathrm{O}$} & \multicolumn{4}{|c|}{$\mathrm{Fe}$ isotopes in $<0.2 \mu \mathrm{m}$ fraction } & \multirow{2}{*}{$\begin{array}{c}\% \text { primary } \\
\text { minerals }\end{array}$} \\
\hline & & & & & & & & & & Bulk rock & $<0.2$ & $\delta^{56} \mathrm{Fe}$ & $2 \mathrm{SD}$ & $\delta^{57 / 54} \mathrm{Fe}$ & $2 S D$ & \\
\hline \multicolumn{17}{|c|}{ Basalts arranged by $\%$ primary minerals } \\
\hline $4522-1$ & 0 & 35 & 0 & $12 *$ & 0 & 0 & 53 & 65 & 0 & 8,1 & & & & & & 93 \\
\hline Novosiolki-1 & 0 & 31 & 0 & 16 & 0 & 0 & 52 & 62 & 0 & 5,6 & & & & & & 91 \\
\hline Skv-0A & 0 & 24 & 5 & 18 & 0 & 0 & 44 & 52 & 0 & 8,4 & & & & & & 85 \\
\hline Skv-0B & 0 & 25 & 0 & $25^{*}$ & 3 & 0 & 47 & 58 & 11 & & & & & & & 85 \\
\hline Mokrany-1B & 0 & 38 & 0 & $20 *$ & 0 & 0 & 33 & 46 & 0 & 6,8 & & & & & & 79 \\
\hline Kob-13 & 0 & 27 & 0 & 28 & 8 & 0 & 38 & 55 & 22 & 10,8 & & & & & & 74 \\
\hline Kob-14 & 6 & 21 & 0 & 28 & 11 & 16 & 19 & 53 & 49 & 9,9 & & & & & & 66 \\
\hline 4603-1 & 0 & 28 & 14 & 29 & 0 & 0 & 29 & 38 & 0 & 11,6 & & & & & & 64 \\
\hline $4504-1 \mathrm{~A}$ & 1 & 44 & 2 & 19 & 7 & 0 & 27 & 49 & 25 & 11,1 & & & & & & 58 \\
\hline $4504-1 A<0.2$ & 0 & & 34 & 41 & 25 & 0 & & & 25 & & 17,8 & $-0,204$ & 0,044 & $-0,305$ & 0,055 & \\
\hline $4466-1$ & 9 & 56 & 12 & 6 & 0 & 0 & 18 & 37 & 50 & 12,6 & & & & & & 53 \\
\hline Mokrany-3B & 2 & 24 & 25 & 33 & 7 & 0 & 8 & 23 & 11 & 16,4 & & & & & & 41 \\
\hline Mokrany-3B $<0.2$ & 0 & & 38 & 49 & 10 & 3 & & & 13 & & 21 & 0,028 & 0,035 & 0,040 & 0,047 & \\
\hline Kob-15 & 11 & 21 & 0 & 24 & 44 & 0 & 0 & 51 & 65 & & & & & & & 31 \\
\hline $4417-1$ & 28 & 33 & 5 & 12 & 21 & 0 & 0 & 32 & 55 & & & & & & & 25 \\
\hline $4417-1<0.2$ & 20 & & 29 & 20 & 19 & 12 & & & 39 & & 18,3 & $-0,025$ & 0,039 & $-0,072$ & 0,059 & \\
\hline $4600-1$ & 15 & & & 39 & 46 & 0 & 0 & 46 & 54 & 17 & & & & & & 7 \\
\hline $4600-1<0.2$ & 0 & & 0 & 58 & 42 & 0 & & & 42 & & 14,7 & $-0,459$ & 0,060 & $-0,735$ & 0,076 & \\
\hline Kob-23 & 0 & 0 & 0 & 5 & 0 & 95 & 0 & 95 & 95 & 10,1 & & $-0,574$ & 0,055 & $-0,843$ & 0,066 & 0 \\
\hline \multicolumn{17}{|c|}{ Chlorophaeite accumulations } \\
\hline Mokrany-3A & 0 & 0 & 40 & 43 & 17 & 0 & 0 & 17 & 17 & 23 & & & & & & 0 \\
\hline \multicolumn{17}{|c|}{ Tuffs arranged by $\%$ quartz } \\
\hline Pinsk-50 & 15 & 0 & 40 & 0 & 44 & 0 & 0 & 44 & 52 & 15,2 & & & & & & \\
\hline Pinsk-44 & 8 & 0 & 43 & 0 & 0 & 50 & 0 & 50 & 54 & 13,4 & & & & & & \\
\hline Pinsk-47D & 22 & 0 & 38 & 0 & 39 & 0 & 0 & 39 & 51 & 14,6 & & & & & & \\
\hline Kob-16 & 30 & 9 & 34 & 0 & 28 & 0 & 0 & 31 & 45 & & & & & & & \\
\hline $4600-2 \mathrm{~A}$ & 47 & 0 & 15 & 20 & 0 & 17 & 0 & 17 & 33 & 15 & & & & & & \\
\hline Pinsk-47A & 15 & 10 & 39 & 0 & 35 & 0 & 0 & 38 & 47 & 15,5 & & & & & & \\
\hline Tashki-10 & 45 & & 28 & 15 & 11 & 0 & & 11 & 21 & 20 & 18,3 & & & & & \\
\hline \multicolumn{17}{|l|}{ Paleosols } \\
\hline $4529-2$ & & & & & & & & & & & 21,3 & & & & & \\
\hline $4517-1$ & & & & & & & & & & & 21,7 & & & & & \\
\hline
\end{tabular}

1508 Table 1. Decomposition of Mössbauer spectra of rocks and selected clay fractions, \% Fe2+ in

1509 total Fe calculated from the decomposition data for bulk rock and clay fraction, oxygen and

1510 iron isotope data, along with \% primary minerals from Supplementary Table 1. 
1512 Table 2. Chemical composition (wt\% SEM/EDS microchemical analyses) of isotropic

1513 chlorophaeite and replacing birefringent smectititic clays in different sites of the basaltic rock

1514 affected by incipient alteration (sample 4522-1). Ferrous state has been assigned to iron in all

1515 analyses.

1516

1517

\begin{tabular}{ccccccccccc}
$\begin{array}{c}\text { Petrographic } \\
\text { entity }\end{array}$ & $\mathrm{Na}_{2} \mathrm{O}$ & $\mathrm{MgO}$ & $\mathrm{Al}_{2} \mathrm{O}_{3}$ & $\mathrm{SiO}_{2}$ & $\mathrm{~K}_{2} \mathrm{O}$ & $\mathrm{CaO}$ & $\mathrm{TiO}_{2}$ & $\mathrm{MnO}$ & $\mathrm{FeO}$ & $\mathrm{S}$ \\
\hline \multirow{3}{\text{Isotropic}}{} & 0,49 & 2,96 & 5,61 & 48,41 & 0,56 & 1,75 & 0,06 & 0,14 & 22,63 & 8 \\
chlorophaeite & 0,45 & 2,84 & 5,89 & 49,39 & 0,54 & 1,79 & 0,11 & 0,15 & 22,54 & 8 \\
& 0,3 & 3,31 & 6,05 & 50,17 & 0,54 & 2 & 0,07 & 0,19 & 23,65 & 8 \\
\hline \multirow{3}{*}{ Smectite } & 0,32 & 4,54 & 8,23 & 47,69 & 0,4 & 1,96 & 0,16 & 0,13 & 19,34 & 8 \\
& 0,09 & 4,25 & 9,73 & 46,23 & 0,87 & 1,81 & 0,34 & 0,13 & 16,45 & \\
& 0,21 & 4,91 & 9,78 & 49,83 & 0,54 & 1,91 & 0,34 & 0,15 & 17,69 & 8 \\
\hline
\end{tabular}

1518

1519 
1520 Table 3. K-Ar data for selected clay fractions containing aluminoceladonite and/or illite-

1521 smectite (cf. Supplementary Table 3).

1522

1523

\begin{tabular}{|c|c|c|c|c|c|c|c|c|}
\hline Sample and fraction & $\begin{array}{c}\text { Mass } \\
{[\mathrm{mg}]}\end{array}$ & $\% \mathrm{~K}_{2} \mathrm{O}$ & $\% \mathrm{~K}$ & $\% 40 \mathrm{Ar}^{*}$ & Age $[\mathrm{Ma}]$ & $\begin{array}{l}\text { Error } \\
\text { [Ma] }\end{array}$ & $\begin{array}{c}\text { Ave. age } \\
\text { [Ma] }\end{array}$ & $\begin{array}{c}\text { Ave. error } \\
{[\mathrm{Ma}]}\end{array}$ \\
\hline \multirow[t]{2}{*}{ Kob-9B 2-0.2 $\mu \mathrm{m}$} & 10,50 & 7,395 & 6,139 & 95,7 & 446,7 & 11,7 & 448,5 & 8,3 \\
\hline & 8,86 & & & 95,8 & 450,3 & 11,8 & & \\
\hline \multirow[t]{2}{*}{ Kob-9B $<0.2 \mu \mathrm{m}$} & 10,91 & 7,355 & 6,105 & 91,4 & 452,2 & 12,0 & 451,1 & 8,4 \\
\hline & 8,93 & & & 97,1 & 449,9 & 11,8 & & \\
\hline \multirow[t]{2}{*}{ Vilch19 $<0.2 \mu \mathrm{m}$} & 10,91 & 4,115 & 3,416 & 93,6 & 442,7 & 13,1 & 439,4 & 9,3 \\
\hline & 8,34 & & & 90,6 & 436,1 & 13,1 & & \\
\hline \multirow[t]{2}{*}{ Ochryny21 2-0.2 $\mu \mathrm{m}$} & 6,97 & 2,885 & 2,395 & 84,5 & 430,6 & 15,8 & 432,6 & 11,1 \\
\hline & 7,71 & & & 94,3 & 434,6 & 15,6 & & \\
\hline \multirow{2}{*}{ Ochryny-21 $<0.2 \mu \mathrm{m}$} & 8,45 & 3,74 & 3,105 & 96,3 & 420,2 & 13,1 & 419,2 & 9,4 \\
\hline & 5,92 & & & 96,4 & 418,2 & 13,3 & & \\
\hline \multirow[t]{2}{*}{ Tashki1 2-0.2 $\mu \mathrm{m}$} & 8,66 & 1,785 & 1,482 & 89,2 & 298,2 & 19,9 & 297,1 & 14,1 \\
\hline & 10,07 & & & 76,2 & 296,1 & 19,9 & & \\
\hline \multirow[t]{2}{*}{ Tashki-1 $<0.2 \mu \mathrm{m}$} & 10,81 & 2,07 & 1,718 & 92,9 & 310,9 & 16,3 & 309,0 & 11,4 \\
\hline & 9,02 & & & 94,9 & 307,2 & 15,9 & & \\
\hline
\end{tabular}

1524

1525 
1526 Table 4. Structural formulae of smectites from Volynian basalts, presented along with

1527 formulae derived from published chemical data of similar materials: griffithite from Ross

1528 (1960) and Komadel et al. (2000), oxysmectites from Dainyak et al. (1981), and ferrosaponite

1529 from Jambor et al. (2004). Formula of chlorite (Kob-23) added to show tendency in chemical

1530 composition of clays.

1531

1532

1533
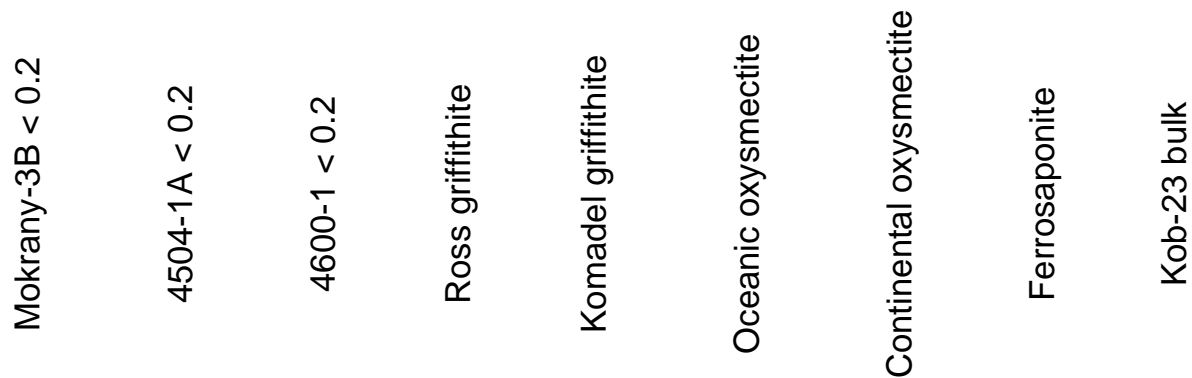

\begin{tabular}{|c|c|c|c|c|c|c|c|c|c|}
\hline Fraction $\mathrm{Fe}^{3+}$ & 0,87 & 0,75 & 0,56 & 0,46 & 0,91 & 0,54 & 0,83 & 0,25 & 0,00 \\
\hline $\mathrm{Si}$ & 3,90 & 3,47 & 3,21 & 3,17 & 3,34 & 3,40 & 3,23 & 2,91 & 3,57 \\
\hline Al IV & 0,10 & 0,53 & 0,75 & 0,83 & 0,66 & 0,59 & 0,47 & 1,03 & 0,43 \\
\hline $\mathrm{Fe}^{\mathrm{IV}}$ & 0,00 & 0,00 & 0,04 & 0,00 & 0,00 & 0,01 & 0,30 & 0,06 & 0,00 \\
\hline $\mathrm{Al}^{\mathrm{VI}}$ & 0,50 & 0,16 & 0,00 & 0,03 & 0,06 & 0,00 & 0,00 & 0,00 & 1,04 \\
\hline $\mathrm{Fe}^{3+}$ & 0,60 & 0,54 & 0,44 & 0,44 & 0,75 & 0,56 & 1,10 & 0,52 & 0,00 \\
\hline $\mathrm{Fe}^{2+}$ & 0,09 & 0,18 & 0,35 & 0,52 & 0,07 & 0,47 & 0,22 & 1,56 & 2,63 \\
\hline $\mathrm{Mg}$ & 1,11 & 1,81 & 2,18 & 1,88 & 1,82 & 1,78 & 1,27 & 0,87 & 1,96 \\
\hline Layer charge & $-0,38$ & $-0,47$ & $-0,42$ & $-0,61$ & $-0,46$ & $-0,44$ & $-0,50$ & $-0,67$ & $-0,13$ \\
\hline No. oct. cat. & 2,31 & 2,68 & 2,97 & 2,87 & 2,70 & 2,80 & 2,59 & 2,95 & 5,63 \\
\hline $\mathrm{Ca}$ & 0,01 & 0,07 & 0,01 & 0,25 & 0,01 & 0,06 & 0,21 & 0,31 & 0,03 \\
\hline $\mathrm{Na}$ & 0,32 & 0,32 & 0,38 & 0,11 & 0,43 & 0,31 & 0,05 & 0,04 & 0,08 \\
\hline $\mathrm{K}$ & 0,04 & 0,01 & 0,02 & 0,00 & 0,01 & 0,02 & 0,03 & 0,01 & 0,01 \\
\hline $\mathrm{Mg}$ & 0,00 & 0,00 & 0,00 & 0,00 & 0,00 & 0,00 & 0,00 & 0,00 & 0,00 \\
\hline $\begin{array}{l}\mathrm{NH}_{4} \\
\text { Interlayer }\end{array}$ & 0,00 & 0,00 & 0,00 & 0,00 & 0,00 & 0,00 & 0,00 & 0,00 & 0,00 \\
\hline charge & 0,38 & 0,47 & 0,42 & 0,61 & 0,46 & 0,44 & 0,50 & 0,67 & 0,15 \\
\hline $\mathrm{Si} /(\mathrm{Si}+\mathrm{Al})$ & 0,87 & 0,83 & 0,81 & 0,79 & 0,82 & 0,85 & 0,87 & 0,74 & 0,71 \\
\hline $\mathrm{Fe} /(\mathrm{Mg}+\mathrm{Fe})$ & 0,38 & 0,29 & 0,27 & 0,34 & 0,31 & 0,37 & 0,56 & 0,71 & 0,57 \\
\hline
\end{tabular}


1535 Table 5. Characteristics of end-member di- and trioctahedral smectite from Volynian basalts

1536 extrapolated using number of atoms in the octahedral sheet given in Table 4.

1537

1538

\begin{tabular}{lcc} 
Smectite & di & tri \\
\hline $\mathrm{Si}$ & 4,00 & 3,16 \\
$\mathrm{Al}^{\mathrm{VI}}$ & 0,72 & 0,00 \\
$\mathrm{Fe}^{3+}$ & 0,68 & 0,44 \\
$\mathrm{Fe}^{2+}$ & 0,00 & 0,34 \\
$\mathrm{Mg}$ & 0,64 & 2,27 \\
$\delta^{180}$ & 24,0 & 14,5 \\
$\delta^{56} \mathrm{Fe}$ & 0,27 & $-0,47$ \\
$\mathrm{ppm}$ LREE & 664,00 & 0,00 \\
ppm & & \\
HREE & 27,00 & 4,00
\end{tabular}

1540 


\section{Supplementary Materials}

\section{Experimental methods}

\section{QXRD of the bulk rock}

1544 The mineral composition of whole rock samples was studied by means of quantitative 1545 X-ray diffractometry (QXRD). A $3 \mathrm{~g}$ sample was spiked with $10 \% \mathrm{ZnO}$, ground in the 1546 McCrone mill with methanol, and a randomly oriented preparation was made by side-loading 1547 (Środoń et al., 2001). The XRD patterns were recorded in 2-65 $2 \theta \mathrm{CuK} \alpha$ range with $15480.02^{\circ} / \mathrm{sec}$ step on Thermo $\mathrm{X}^{\prime}$ tra diffractometer, the mineral phases were identified and then 1549 quantified using QMIN software (by Dr. Marek Szczerba), which matches the sum of the 1550 diffraction patterns of pure mineral standards with the pattern of a studied rock sample, 1551 allowing for manual corrections. Dioctahedral and trioctahedral clays were quantified as 1552 groups by careful 060 reflection fitting (Środoń et al., 2001) and split into species by fitting 1553 the peaks in the $17-35^{\circ} 2 \theta$ range. Chlorophaeite samples, available in quantities too small to 1554 conduct regular QXRD, were analyzed only qualitatively in glass capillaries in 4-39 $2 \theta$ range, as random powders without the spike.

QMIN software does not provide errors of mineral phase determination. Uncertainty 1557 of the QXRD analysis can be however evaluated from the results of Reynolds Cup quantitative mineral analysis international round robin (Raven and Self, 2017). We got $4^{\text {th }}$ place in 2018 Reynolds Cup, with the absolute error per major components of $2.4 \%$. Considering much simpler mineralogy of the samples analyzed in this study than of the samples of Reynolds Cup, the uncertainty of QXRD measurements should be even smaller.

\section{Clay fraction separation}

1564 The clay fractions $2-0.2$ and $<0.2 \mu \mathrm{m}$ were separated from ca. $50 \mathrm{~g}$ of the bulk rock after 1565 ultrasonic dispersion of the crushed rock in deionized water. Standard chemical treatments 1566 (Jackson, 1975) were used for samples prepared for K-Ar dating, but they were avoided in 1567 case of the Mössbauer and FTIR studies, in order to minimize the oxidation of structural iron. 
1568 The fractions were collected by centrifugation, coagulation by adding concentrated $\mathrm{NaCl}$ 1569 solution, dialysis, and freeze-drying.

\section{XRD of clay fraction}

Clay mineral identification in the bulk rock was verified and made more accurate by studying 2-0.2 and $<0.2 \mu \mathrm{m}$ fractions of selected samples. XRD patterns were recorded in airdried and glycolated state of the oriented slides, prepared by sedimentation of $10 \mathrm{mg}$ clay $/ \mathrm{cm}^{2}$ from a sonified water suspension, with $4 \% \mathrm{MoS}_{2}$ as the internal standard. The collected XRD patterns were first analyzed using Mering rules for the identification of clay minerals (Moore and Reynolds, 1997) and then percent smectite layers in mixed-layer illite-smectite (\%S) was measured from the selected peak positions on glycolated patterns, using the regressions based on data of Środoń et al. (2009).

\section{K-Ar dating of illite}

Na-exchanged, 2.0-0.2 and $<0.2 \mu \mathrm{m}$ clay fractions containing illite-smectite and aluminoceladonite were dated by K-Ar method to establish the age of crystallization of these minerals. All the measurements were performed at the Institute of Geological Sciences, Polish Academy of Sciences in Kraków using Nu Instruments Noblesse multicollector noble-gas spectrometer. Four portions of samples: two $10 \mathrm{mg}$ and two $50 \mathrm{mg}$, were weighted using Sartorius mass balance with precision of $0.01 \mathrm{mg}$. A small quantity of $\mathrm{CuO}$ (approximately $0.1 \mathrm{mg}$ ) was added to the two lightest portions. These samples were then wrapped in an Alfoil and proceeded to radiogenic argon measurements. Two heaviest portions were weighted directly on platinum evaporators and proceeded to potassium measurements. All the samples were equilibrated in the ambient atmosphere (air-dry state) and weighted one after another in order to minimize the errors due to relative humidity affecting clay hydration.

Radiogenic argon measurements were performed on $\mathrm{Nu}$ Instruments Noblesse multicollector noble-gas spectrometer (NG039). The spectrometer is equipped with a Niertype ion-source, $75^{\circ}$ magnetic sector, two quadrupole lenses and a collector block. The collectors assembly consists of a Faraday detector (FAR) and three ETP ion-counting electron multipliers (IC0, IC1, IC2). The high mass isotope $\left({ }^{40} \mathrm{Ar}\right)$ is switchable between Faraday and

1596 IC0 multiplier, depending on the height of the measured signal. Due to high mass resolving power (MRP), which is $\sim 5400$, it is possible to resolve combined peaks of ${ }^{36} \mathrm{Ar}+\mathrm{H}^{35} \mathrm{Cl}$ from 
1598 peaks of ${ }^{36} \mathrm{Ar}+\mathrm{H}^{35} \mathrm{Cl}+{ }^{12} \mathrm{C}_{3}$. The signal of all argon isotopes was always calculated as a 1599 difference between measurement for sample and signal measured directly before, when ion pump was pumping the interior of the spectrometer. It was done to correct for background level of ${ }^{36} \mathrm{Ar}+\mathrm{H}^{35} \mathrm{Cl},{ }^{38} \mathrm{Ar}+\mathrm{H}^{37} \mathrm{Cl}$ and also of ${ }^{40} \mathrm{Ar}$ that is always leaking in very small quantities to the spectrometer through gaskets (background signal was at around 60, 40 and 400 cps, respectively; while e.g. for GL-O it is at: 2000, 30000, 5000000 cps, respectively). Amount of ${ }^{35} \mathrm{Cl}$ was also always monitored prior to the sample and when the sample was being measured: differences are maximally of few percent. This indirectly indicates that level of $\mathrm{H}^{35} \mathrm{Cl}$ was constant prior and during measurements and, considering very low background level of ${ }^{36} \mathrm{Ar}+\mathrm{H}^{35} \mathrm{Cl}$ peak, the used correction was reasonable.

Extraction-purification line with all-metal valves is attached to the Noblesse spectrometer. The Al-foil wrapped portions were loaded into a glass container, which is a part of the line. The aliquots were subsequently evacuated to approximately $10^{-10}$ mbar pressure. The line was heated overnight at $200^{\circ} \mathrm{C}$ to remove all gases adsorbed on metal parts of the line. Samples were, however, not heated, to avoid any ${ }^{40} \mathrm{Ar}_{\mathrm{rad}}$ removal. The reactor was running several blank measurements to achieve signal of ${ }^{40} \mathrm{Ar}$ lower than $0.01 \mathrm{~V}$ measured on FAR detector (corresponding to $650000 \mathrm{cps}$ on multiplier). Then, each sample was melted in a double-vacuum resistant crucible at above $1200^{\circ} \mathrm{C}$ (assessed visually). $\mathrm{CuO}$ added to the samples enhances oxidation of organic matter during this step. Titanium sponge (>99.99\% Ti) was always put to the place of the reactor $(\sim 0.5 \mathrm{~g})$, where samples are heated. This was a first cleaning level of gases extracted from the samples. Most of the cleanup was achieved when temperature of the reactor was decreasing, which was monitored on Pirani gauge.

Pure ${ }^{38} \mathrm{Ar}$ produced by the Institute for Inorganic and Physical Chemistry of Bern University was used as the spike. It was introduced to the extraction line after the sample extraction using a calibrated pipette, built at Heidelberg University. Impurities of ${ }^{40} \mathrm{Ar}$ and ${ }^{36} \mathrm{Ar}$ in spike are regularly monitored and the final results are corrected for these impurities. The final purification of argon was carried out in an isolated section of the line by a getter pump (D-100, SAES Getters), previously baked overnight to remove excess argon. The amount of gases poured to the spectrometer were optimized to keep ${ }^{40} \mathrm{Ar}$ at level below 0.15

$1627 \mathrm{~V}$, because otherwise fractionation on Nier ion source can occur (Kellett and Joyce, 2014).

1628 Gas aliquot released from the sample was measured three times or more by opening and closing valves of the line in a certain sequence. 

international standard GL-O (Odin, 1982: $24.85 \pm 0.2410^{-6} \mathrm{~cm}^{3} / \mathrm{g} \mathrm{STP}{ }^{40} \mathrm{Ar}_{\mathrm{rad}}$ ). This standard is measured at least two times with every batch of the samples. Standard deviation of received results for GL-O is \pm 0.09 ( $\pm 0.38 \%) 10^{-6} \mathrm{~cm}^{3} / \mathrm{g} \mathrm{STP}{ }^{40} \mathrm{Ar}_{\mathrm{rad}}$ for 19 measurements. Biotite LP6 was also tested for comparison (Odin, 1982: $43.26 \pm 0.4410^{-6} \mathrm{~cm}^{3} / \mathrm{g} \mathrm{STP}{ }^{40} \mathrm{Ar}_{\mathrm{rad}}$ ) and have $43.08 \pm 0.41( \pm 0.96 \%) 10^{-6} \mathrm{~cm}^{3} / \mathrm{g} \mathrm{STP}{ }^{40} \mathrm{Ar}_{\text {rad. }}$. Every day, the ${ }^{40} \mathrm{Ar} /{ }^{36} \mathrm{Ar}$ and ${ }^{40} \mathrm{Ar} /{ }^{38} \mathrm{Ar}$ ratios are measured for air sample aliquots, delivered from a calibrated air pipette. Based on this results ${ }^{40} \mathrm{Ar} /{ }^{36} \mathrm{Ar}$ and ${ }^{40} \mathrm{Ar} /{ }^{38} \mathrm{Ar}$ ratios were corrected for instrument mass fractionation and detector efficiencies assuming atmospheric ratios of $\left({ }^{40} \mathrm{Ar} /{ }^{36} \mathrm{Ar}\right)_{\text {air }}=298.57$ and $\left({ }^{40} \mathrm{Ar} /{ }^{38} \mathrm{Ar}\right)_{\text {air }}$ $=1583.5$ (Lee et al., 2006). The potassium contents were measured using Sherwood Model 420 flame photometer. The maximum error of this measurement was estimated to be equal $0.03 \% \mathrm{~K}$. Based on 6 measurements, K content in GL-O glauconite was slightly higher: 6.61 $\pm 0.02 \%$, than that of standard: $6.56 \pm 0.06 \%$ (Odin, 1982). LP-6 biotite has slightly lower amount of $\mathrm{K}: 8.27 \pm 0.022 \%$ (4 measurements) comparing to reference value: $8.33 \pm 0.03 \%$ (Odin, 1982). Both measured standards are within reference ranges assuming $0.03 \% \mathrm{~K}$ error. uncertainties of:

1647 - spectrometric measurement of argon isotopes determined by spectrometer's software 1648 delivered by $\mathrm{Nu}$ Instruments - sum of uncertainty for background and sample,

1649 - weighting - assumed to be equal to $\pm 0.03 \mathrm{mg}$,

1650 - potassium measurements - equal to $\pm 0.03 \%$ of absolute potassium content, - normalization of amount of ${ }^{38} \mathrm{Ar}$ in spike based on dating of GL-O standard - assumed to be equal to $\pm 0.4 \%$,

- assessment of ${ }^{40} \mathrm{Ar} /{ }^{36} \mathrm{Ar}$ and ${ }^{40} \mathrm{Ar} /{ }^{38} \mathrm{Ar}$ ratios, measured every day for air aliquots - equal to $\pm 0.017 \%$ and $\pm 0.013 \%$, respectively.

\section{Chemistry of the bulk rock and clay separates}

Samples were ground in an agate mill and analyzed for the majority of elements at the Bureau Veritas Mineral Laboratories (ACME) in Perth, Australia using a combo package, which requires a single lithium borate fusion and provides major elements from X-Ray

1659 Fluorescence (XRF) and trace elements (including REE) from Laser Ablation Inductively 1660 Coupled Plasma Mass Spectrometry (LA-ICP-MS) on the same fused disc. Samples were pre 1661 oxidized using 66:34 flux containing $10 \% \mathrm{LiNO}_{3}$ in order to convert sulfides into sulfates. All 
1662 elements were measured on the oven dry $\left(105^{\circ} \mathrm{C}\right)$ weight basis. Loss on Ignition (LOI) was

1663 determined from a separate $1 \mathrm{~g}$ split using a Thermo Gravimetric Analysis (TGA) system with 1664 furnaces set to 110 and $1000^{\circ} \mathrm{C}$. Boron content was measured by the Prompt-Gamma Neutron 1665 Activation Analysis (PGNAA) with $0.5 \mathrm{ppm}$ detection limit at the Activation Laboratories, 1666 Canada.

1667 Mössbauer spectroscopy of the bulk rock and clay separates

The Mössbauer spectroscopy was used in order to quantify the oxidation state of iron (recent review of the method applied to minerals in Murad, 2013). The Mössbauer spectra, both for the bulk rock and for mineral separates, were recorded in the transmission geometry at room temperature using a Wissel spectrometer. In addition, both fresh and hydrothermally altered basalts were studied as reference. The samples were prepared in form of pellets, 12 $\mathrm{mm}$ in diameter, containing $100 \mathrm{mg}$ specimen mixed with $200 \mathrm{mg}$ lucide powder. The velocity scale calibration was determined from $\alpha$-Fe foil standard.

1675 The spectra were evaluated with the use of WinNormos-for-Igor program. The spectra were 1676 decomposed into sets of Zeeman sextets and quadrupole doublets. For each subspectrum the 1677 hyperfine field $B$, isomer shit IS and quadrupole splitting $Q S$ were determined and used for 1678 the identification of the iron bearing fractions. For natural mineralogical samples, due to the 1679 distribution of the hyperfine parameters and overlapping of the subspectra, such identification 1680 may be sometimes ambiguous. However, the distinction between $\mathrm{Fe}^{2+}$ and $\mathrm{Fe}^{3+}$ states is obvious, due the significant difference in IS. The $\mathrm{Fe}^{2+} / \mathrm{Fe}^{3+}$ ratio was determined as the area ratio of the corresponding subspectra. The thickness saturation effects and differences in the recoil free fraction of $\mathrm{Fe}$ in different states were not included into analysis. The typical accuracy of the relative contribution of each component is $1 \%$. The $\% \mathrm{Fe}^{2+}$ values for clay fractions are less accurate, in particular if abundant pyroxene is present.

Fe isotopes of the bulk rock and clay separates

$1687 \mathrm{Fe}$ isotope analyses $\left({ }^{56} \mathrm{Fe} /{ }^{54} \mathrm{Fe}\right.$ and ${ }^{57} \mathrm{Fe} /{ }^{54} \mathrm{Fe}$ ratios, reported as $\delta^{56} \mathrm{Fe}$ and $\left.\delta^{57 / 54} \mathrm{Fe}\right)$ were 1688 performed for bulk rock samples and clay separates to trace possible microbial influence (cf. 1689 Kappler et al., 2010). The measurements were conducted by ALS Scandinavia AB in Lulea, 1690 Sweden, by MC-ICP-MS technique of Malinovsky et al. (2003). 
1692 Oxygen isotopes were measured by Actlabs (Canada). Oxygen was extracted from $5 \mathrm{mg}$ 1693 samples at $550-600^{\circ} \mathrm{C}$ according to the conventional $\mathrm{BrF}_{5}$ procedure of Clayton and Mayeda 1694 (1963) and analyzed via dual inlet on a Thermo-Finnigan DeltaPlusXP Isotope-Ratio Mass 1695 Spectrometer (IRMS). The $\delta^{18} \mathrm{O}$ values are reported in permil (\%o) relative to Vienna Standard 1696 Mean Ocean Water (VSMOW), with a precision of about $0.1 \%$.

\section{FTIR measurements}

Middle infrared (MIR) investigations $\left(4000-400 \mathrm{~cm}^{-1}\right)$ were performed in transmission mode using a KBr beam-splitter and a DTGS/KBr detector on a Nicolet 6700 FTIR spectrometer. The spectra were obtained using $\mathrm{KBr}$ pressed pellets, $13 \mathrm{~mm}$ in diameter. The pellets were prepared by mixing $1 \mathrm{mg}$ of sample with $150 \mathrm{mg}$ of well ground $\mathrm{KBr}$. Then, the mixture was pressed for $5 \mathrm{~min}$ at $5 \mathrm{kbars}$ and $4 \mathrm{~min}$ at $12 \mathrm{kbars}$. The pellets thus prepared were kept at $110{ }^{\circ} \mathrm{C}$ overnight in an oven before analyses. The spectra were recorded at $4 \mathrm{~cm}^{-1}$ resolution, from 100 co-added scans. Near infrared (NIR) spectra $\left(7500-4000-\mathrm{cm}^{-1}\right)$ were acquired with a Thermo-Scientific Integrating Sphere (diffuse reflectance) equipped with an internal InGaAs detector, set on a Thermo-Scientific Nicolet 6700 FTIR spectrometer. A white light source was used, associated with a $\mathrm{CaF}_{2}$ beam splitter. The resolution was set at 4 $\mathrm{cm}^{-1}$ with the co-additions of 100 scans. Samples were analyzed directly on the integrating sphere.

\section{Organic geochemistry}

Seven bulk rock samples (basalts or clays in basalt cavities: 4600-1, 4600-3A, 46003B, and paleosols on basalts: 4504-3, 4504-4, 4504-5 and 4517-1) were used in the organic geochemistry study. Total carbon (TC), total inorganic carbon (TIC), and total sulphur (TS) contents were measured using an Eltra CS-500 IR-analyzer with a TIC module. TC was determined using an infrared cell detector in $\mathrm{CO}_{2}$ gas evolved by combustion in an oxygen atmosphere. TIC contents were derived from a reaction with hot $15 \%$ hydrochloric acid; the resulting $\mathrm{CO}_{2}$ was determined using an infrared detector. Total organic carbon (TOC) was calculated as the difference between TC and TIC. Calibration was made according to the Eltra standards. The samples crushed to ca. 100 mesh were extracted using a dichloromethane (DCM)-methanol mixture (1:1 v:v) with an accelerated Dionex ASE 350 solvent extractor. 
1724 low extract yields, samples were not separated into fractions. The $n$-hexane aliquots of the

1725 total extracts were converted to trimethylsilyl derivatives via a reaction with N,O-bis-

1726 (trimethylsilyl)trifluoroacetamide (BSTFA) and pyridine for $3 \mathrm{~h}$ at $70{ }^{\circ} \mathrm{C}$. A blank sample

1727 (silica gel) was analysed using the same procedure. Only trace amounts of phthalates and fatty

1728 acids (FAs) were detected. All solvents were spectroscopically pure and the $n$-hexane for

1729 derivatization was of super-dehydrated grade. The GC-MS analyses were carried out using an

1730 Agilent Technologies 7890A gas chromatograph and an Agilent 5975C mass spectrometer

1731 with a Triple-Axis Detector at the Faculty of Earth Sciences, Sosnowiec, Poland. Helium (6.0

1732 Grade) was used as the carrier gas at a constant flow of $2.6 \mathrm{ml} / \mathrm{min}$. Separation was performed

1733 in either of two fused silica columns:

1734 (i) $\mathrm{J} \& \mathrm{~W}$ HP5-MS (60 $\mathrm{m} \times 0.32 \mathrm{~mm}$ i.d., $0.25 \mu \mathrm{m}$ film thickness $)$ coated with a chemically

1735120 bonded phase (5\% phenyl, 95\% methylsiloxane). The GC oven temperature was

1736 programmed from $45^{\circ} \mathrm{C}(1 \mathrm{~min})$ to $100^{\circ} \mathrm{C}$ at $20^{\circ} \mathrm{C} / \mathrm{min}$, then to $300{ }^{\circ} \mathrm{C}$ (held for $\left.60 \mathrm{~min}\right)$ at 3

$1737{ }^{\circ} \mathrm{C} / \mathrm{min}$. Solvent delay $=10 \mathrm{~min}$.

1738 (ii) J\&W DB35-MS (60 $\mathrm{m} \times 0.25 \mathrm{~mm}$ i.d., $0.25 \mu \mathrm{m}$ film thickness) coated with a chemically

1739 bonded phase (35\% phenyl, 65\% methylsiloxane). The GC oven temperature was

1740 programmed from $50{ }^{\circ} \mathrm{C}(1 \mathrm{~min})$ to $120^{\circ} \mathrm{C}$ at $20^{\circ} \mathrm{C} / \mathrm{min}$, then to $300{ }^{\circ} \mathrm{C}$ (held for $60 \mathrm{~min}$ ) at 3

$1741{ }^{\circ} \mathrm{C} / \mathrm{min}$. Solvent delay $=15 \mathrm{~min}$. The GC column outlet was connected directly to the ion

1742 source of the MSD. The GC-MS interface was at $280^{\circ} \mathrm{C}$, while the ion source and the

1743 quadrupole analyser were at 230 and $150^{\circ} \mathrm{C}$, respectively. Spectra were recorded from $\mathrm{m} / \mathrm{z}$

$1744 \quad 45-550(0-40 \mathrm{~min})$ and $\mathrm{m} / \mathrm{z}$ 50-700 (> $40 \mathrm{~min})$. The mass spectrometer was operated in the

1745 electron impact mode (ionisation energy $70 \mathrm{eV}$ ).

1746

1747

Petrographic observations

1748

1749

Petrographic studies were performed on thin sections and rock fragments using a 1750 polarizing optical microscope (Nikon Eclipse E600POL) and a JEOL IT 500 SEM equipped 1751 with an EDS (BRUKER XFlash 4030 Silicon drift detector). SEM observations were 1752 performed in secondary electron imaging mode (SEI) for morphological investigations and 1753 backscattering electron mode (BSE) on carbon-coated thin sections for imaging of chemical 1754 contrast and selection of local sites for punctual chemical analysis. Analytical conditions were $175515 \mathrm{kV}, 1 \mathrm{nA}$, a counting time of $60 \mathrm{~s}$ and a working distance of $16.5 \mathrm{~mm}$. The standards used 1756 for EDS consisted of albite $(\mathrm{Na}, \mathrm{Al}, \mathrm{Si})$, almandine $(\mathrm{Mg}, \mathrm{Fe})$, diopside $(\mathrm{Ca})$, orthoclase $(\mathrm{K})$ 1757 and spessartine (Mn). Matrix corrections were performed using integrated programs (a 
1758 PhiRhoz correction). Reproducibility of the standard analyses was close to $1.5 \%$ for all of the 1759 elements, except $\mathrm{Na}(3 \%)$.

\section{References}

1761 Clayton, R.N., Mayeda, T.K., 1963. The use of bromine pentafluoride in the extraction of 1762 oxygen from oxides and silicates for isotopic analysis. Geochimica et Cosmochimica Acta 27, $1763 \quad 43-52$.

1764

1765 Jackson, M.L., 1975. Soil Chemical Analysis - advanced Course. 2nd edition, published by 1766 the author, Madison, Wisconsin, $895 \mathrm{pp}$.

1767 Kappler, A., Johnson, C.M., Crosby, H.A., Beard, B.L., Newman, D.K., 2010. Evidence for 1768 equilibrium iron isotope fractionation by nitrate-reducing iron(II)-oxidizing bacteria. 1769 Geochimica et Cosmochimica Acta 74, 2826-2842.

1770 Kellet, D., Joyce N., 2014. Analytical details of single- and multicollection 40Ar/39Ar 1771 measurements for conventional step-heating and total-fusion age calculation using the $\mathrm{Nu}$ 1772 Noblesse at the Geological Survel of Canada. Geological Survey of Canada, Technical Note $17738,27 \mathrm{pp}$.

1774

1775 Lee, J.Y., Marti, K., Severinghaus, J.P., Kawamura, K., Yoo, H.S., Lee, J.B., \& Kim, J.S., 1776 2006. A redetermination of the isotopic abundances of atmospheric Ar. Geochimica et 1777 Cosmochimica Acta 70, 4507-4512.

1778

1779 Malinovsky, D., Stenberg, A., Rodushkin, I., Andren, H., Ingri, J., Ohlander, B., Baxte, D.C., 1780 2003. Performance of high resolution MC-ICP-MS for Fe isotope ratio measurements in 1781 sedimentary geological materials. Journal of Analytical Atomic Spectrometry 18, 687-695. 
1782 Moore, D.M., Reynolds Jr., R.C., 1997. X-ray Diffraction and the Identification and Analysis 1783 of Clay Minerals. Oxford University Press, Oxford, 378 pp.

1784 Murad, E., 2013. Mossbauer Spectroscopy. In: Hanbook of Clay Science, Bergaya, F., 1785 Lagaly, G. (Eds.), Elsevier, 11-24.

1786

1787 Odin, G.S. and 35 Collaborators, 1982. Interlaboratory Standards for Dating 1788 Purposes. In: Odin, G.S, ed., Numerical Dating in Stratigraphy. Wiley and 1789 Sons, Chichester, 123-149.

1790 Raven, M.D., Self, P.G., 2017. Outcomes of 12 years of the Reynolds Cup quantitative 1791 mineral analysis round robin. Clays and Clay Minerals 65, 122-134.

1792 Środoń, J., Drits, V.A., McCarty, D.K., Hsieh, J.C.C., Eberl, D.D., 2001. Quantitative X-ray 1793 diffraction analysis of clay-bearing rocks from random preparations. Clays and Clay Minerals $1794 \quad 49,514-528$.

1795

1796

1797 Inline Supplementary Figure 1. Random powder XRD patterns of the bulk rock, with $\mathrm{ZnO}$

1798 internal standard, illustrating the compositional variability of Volyn tuffs, from felsic (top) to 1799 basic (bottom), with rhyodacite Skv-0C as reference. 


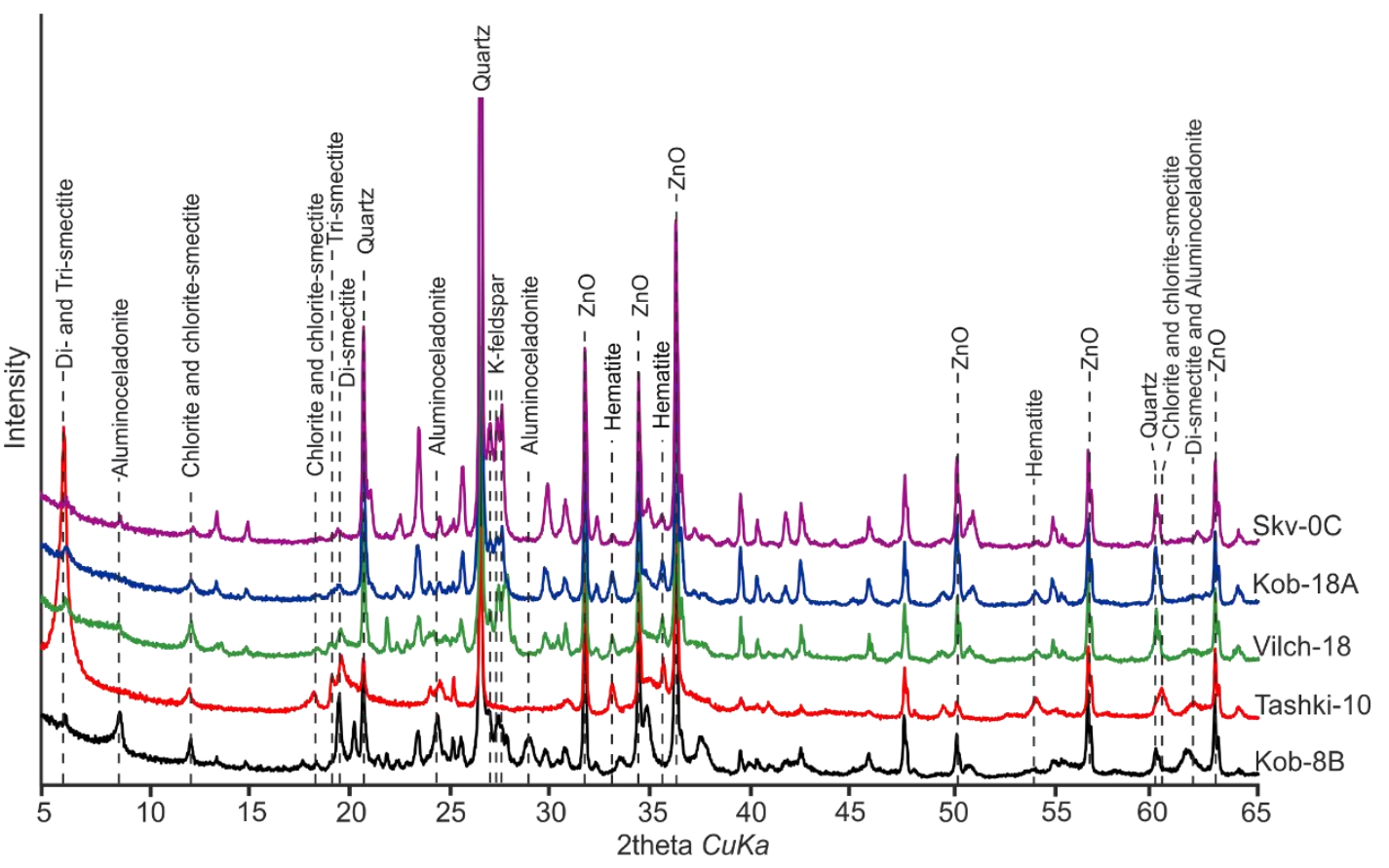

1802

1803 Inline Supplementary Figure 2. Oriented glycolated XRD patterns of $<0.2 \mu \mathrm{m}$ clay fractions

1804 (with $\mathrm{MoS}_{2}$ as internal standard), representative for the variability encountered in basalts and 1805 green clays from veins and cavities in basalt.

1806

1807

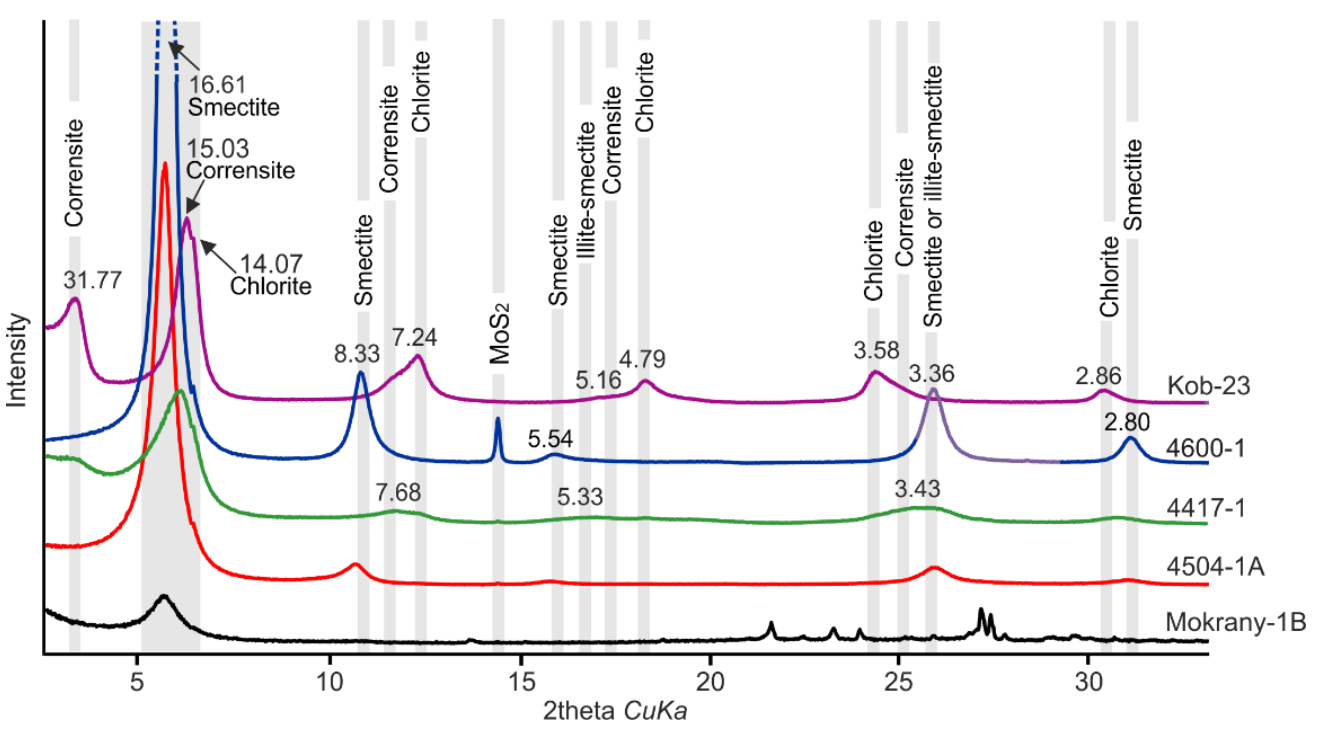

1808 
1810 Inline Supplementary Figure 3. Random powder XRD patterns of $<0.2 \mu \mathrm{m}$ basalt clay

1811 fractions and $<2 \mu \mathrm{m}$ fraction of griffithite, documenting coexistence of di- and trioctahedral

1812 smectite. The reference griffithite sample from Griffith Park, California, was provided by Dr.

1813 Jana Madejova.

1814

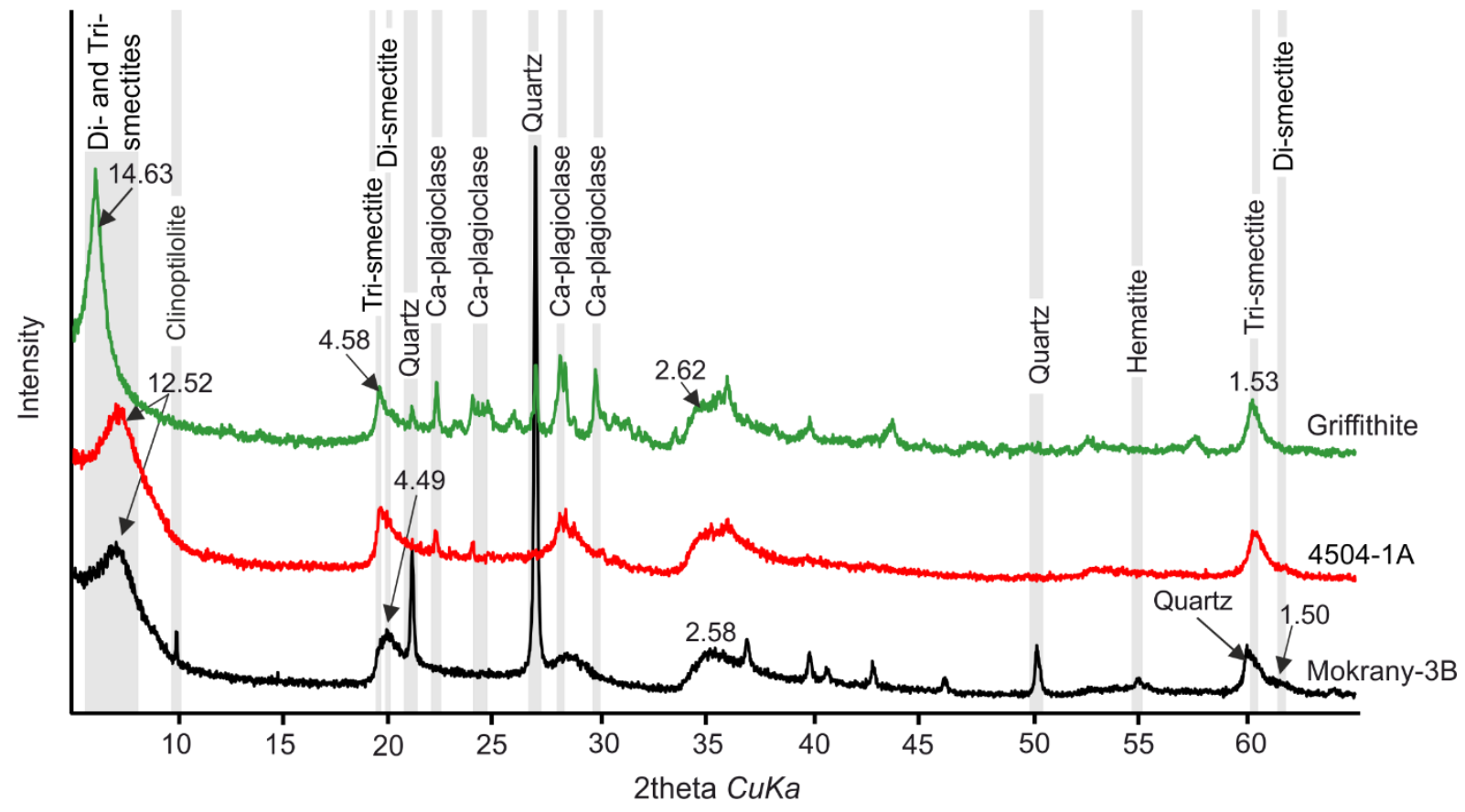

1816

1817

1818

1819 Inline Supplementary Figure 4. Oriented glycolated XRD patterns of $<0.2 \mu \mathrm{m}$ clay fractions, representative for the variability encountered in tuffs. 


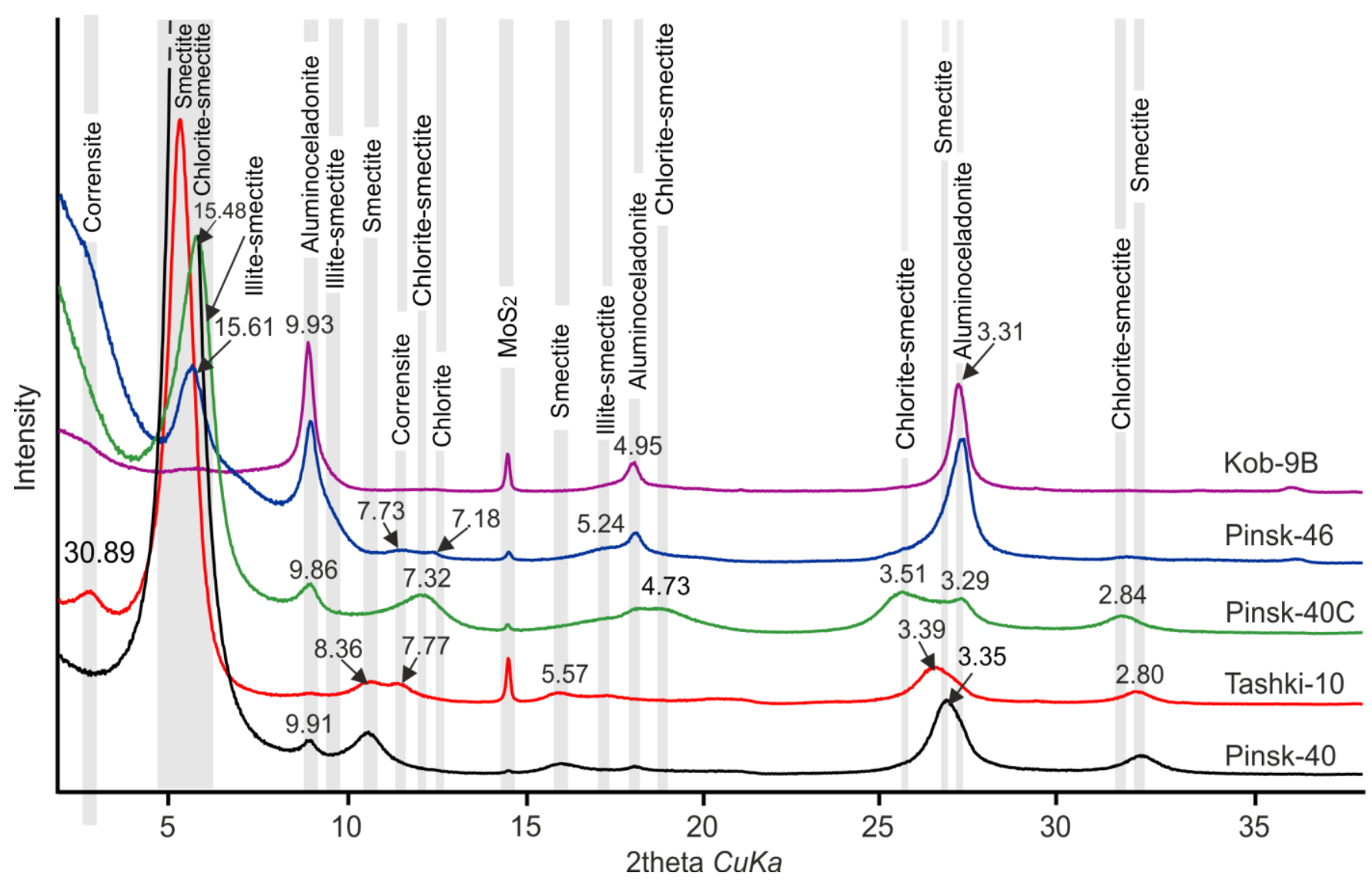

1822

1823

1824

1825

1826

1827 Inline Supplementary Figure 5. ${ }^{57} \mathrm{Fe}$ room temperature Mössbauer spectra of minerals, used 1828 for decomposing spectra of bulk rocks (results of decomposition in Table 1).

1829 

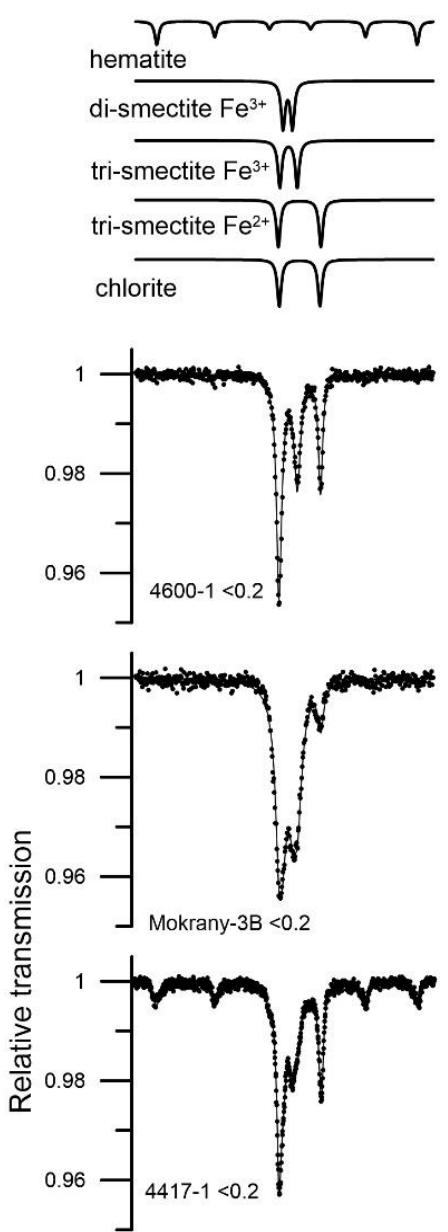

1830

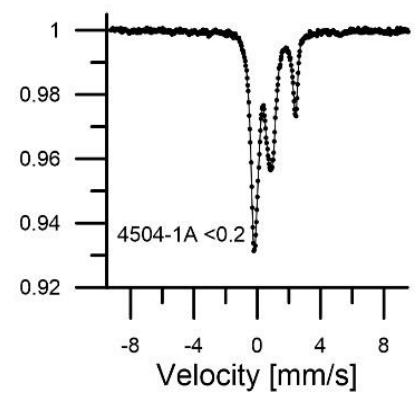

1831

1832

1833

1834

1835

1836

1837

1838 
1840 Inline Supplementary Figure 6. Relationship between \% plagioclase from XRD and \% $\mathrm{CaO}$ in

1841 basalts of variable degree of alteration. Three samples off the general trend (blue diamonds)

1842 contain calcite veinlets.

1843

1844

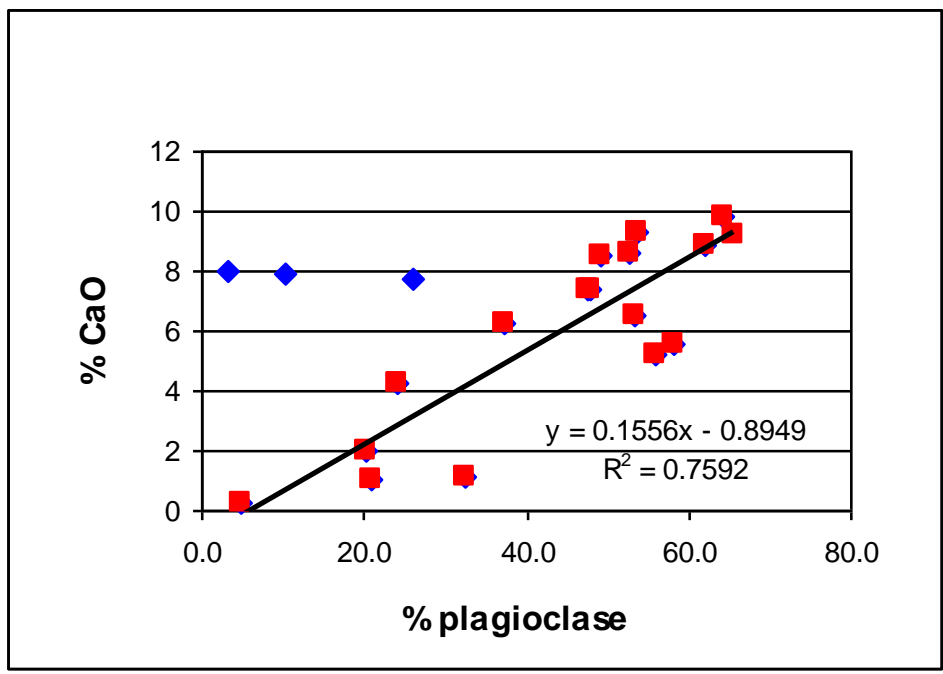

1845

1846

1847

1848

1849

1850

1851

1852

1853

1854

1855

1856

1857 
1861 Inline Supplementary Figure 7. Relationship between \% dioctahedral clays from XRD and 1862 ppm boron in basalts of variable degree of alteration.

1863

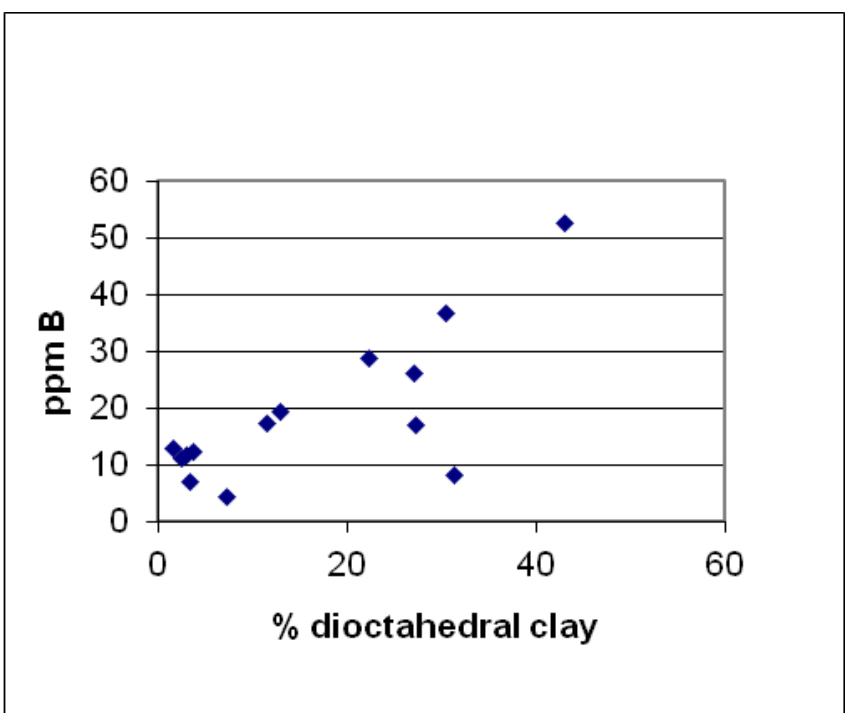

1865

1866

1867

1868

1869

1870

1871 Inline Supplementary Figure 8. Relationship between $\% \mathrm{~K}_{2} \mathrm{O}$ calculated from XRD contents

1872 of $\mathrm{K}$-feldspar (assuming $12 \% \mathrm{~K}_{2} \mathrm{O}$ ) and dioctahedral clay $\left(6 \% \mathrm{~K}_{2} \mathrm{O}\right.$ ) and measured $\% \mathrm{~K}_{2} \mathrm{O}$ in 1873 basalts of variable degree of alteration.

1874 


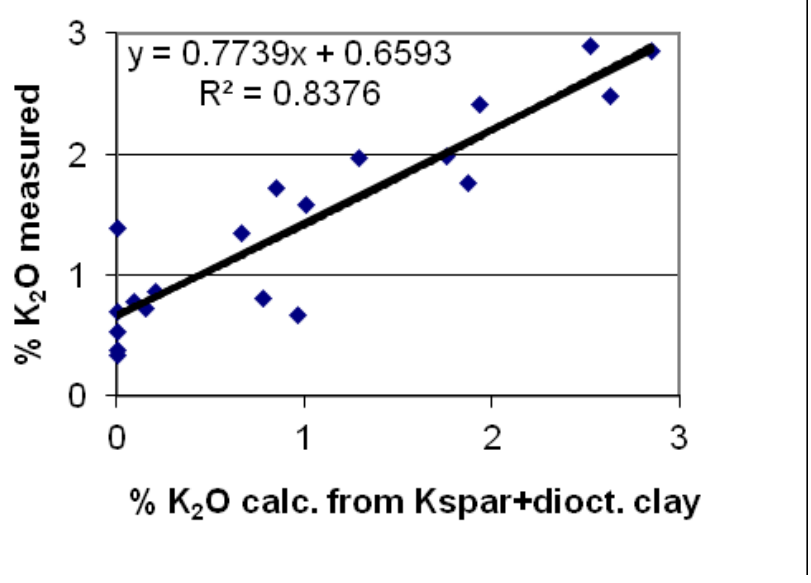

1876

1877

1878

1879

1880

1881

1882

1883

1884 Inline Supplementary Figure 9. Relationship between $\% \mathrm{P}_{2} \mathrm{O}_{5}$ and ppm LREE in bulk rocks. 1885 


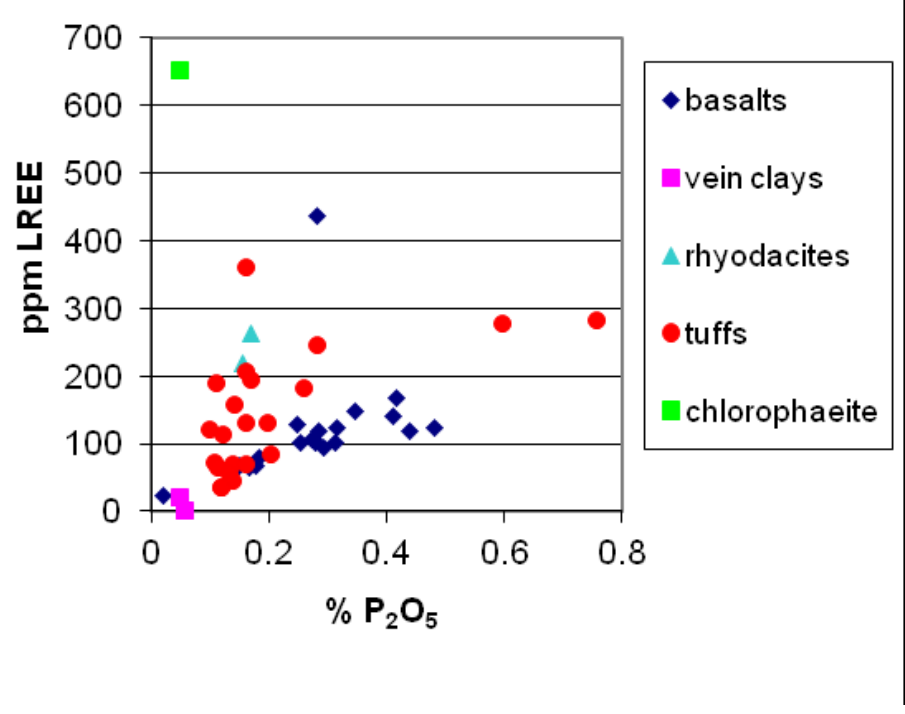

1890 Inline Supplementary Figure 10. Quantitative evolution of secondary minerals in the course of 1891 basalt hydrothermal alteration(traced by percent of primary minerals).

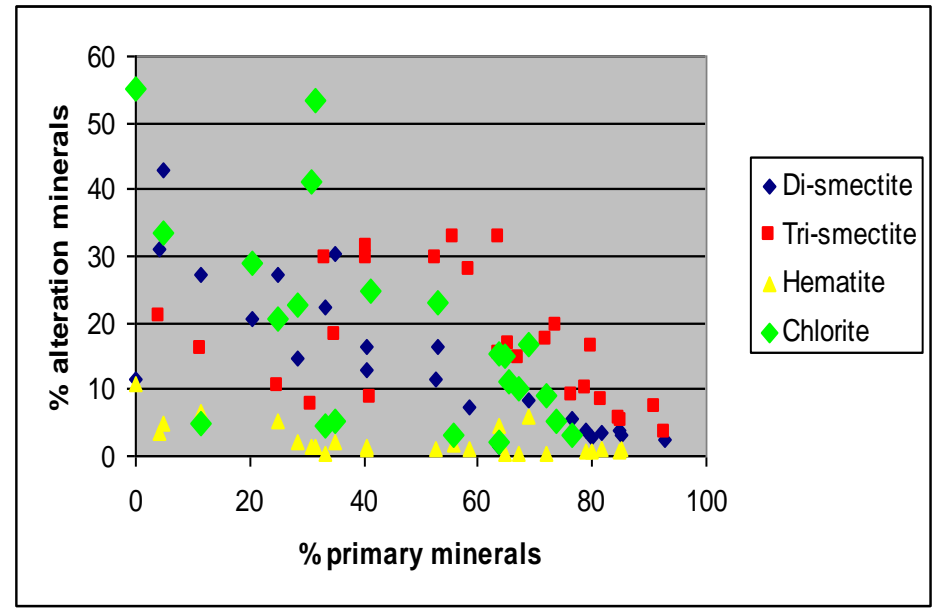

1901 
1912 Inline Supplementary Figure 11. Differentiation of tuffs into felsic (close to rhyodacite) and 1913 basaltic, based on quartz and K-feldspar XRD contents.

1914

1915

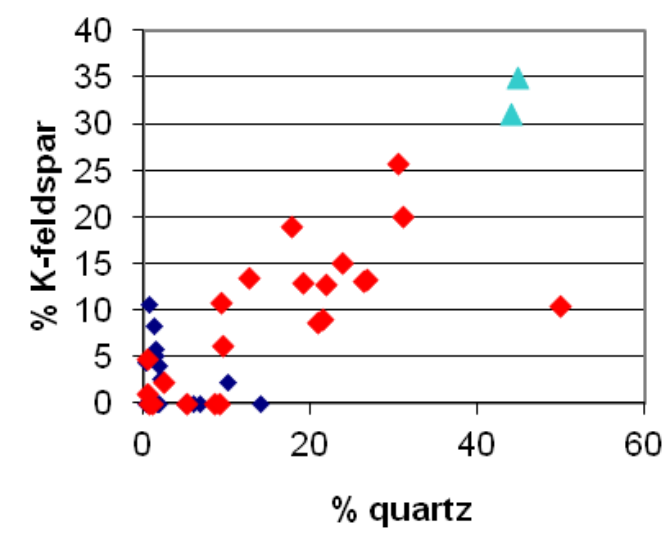

- basalts $\Delta$ rhyodacites

$\bullet$ tuffs

1916

1917

1918

1919

1920

1921 
1923 Inline Supplementary Figure 12. Chemical variability of tuffs (felsic vs. basaltic) traced using 1924 the most immobile trace elements.

1925

1926

1927

1928

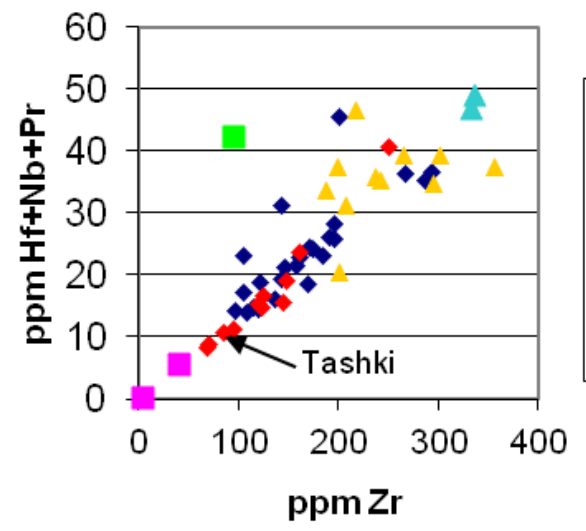

- basalts

chlorophaeite

-vein clays

$\Delta$ rhyodacites

$\triangle$ felsitic tuffs

- basic tuffs

1929

1930

1931

1932

1933

1934

1935 Inline Supplementary Figure 13. Chemical differences between basalts and tuffs illustrated

1936 for a single profile (Kobryn) using the most immobile trace elements.

1937 


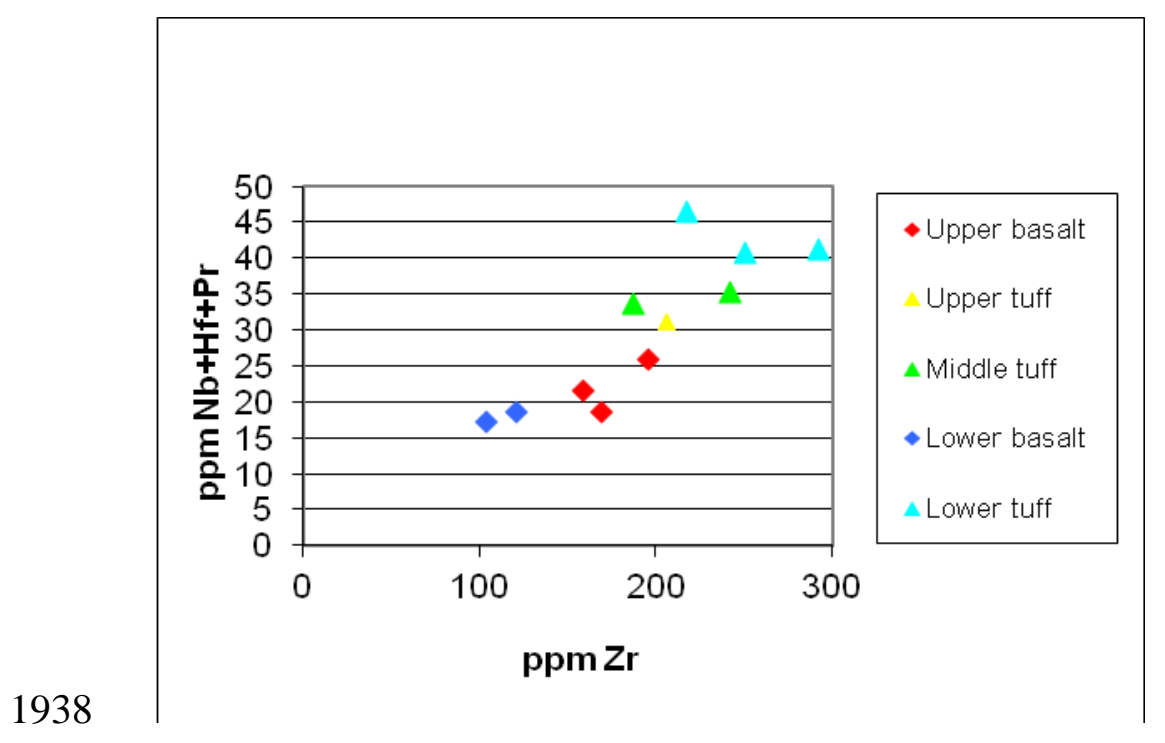

1939 